\title{
Cypella (Iridaceae): What do we know about the diversity of the genus?
}

\author{
Leonardo Paz Deble ${ }^{1,3}$ Fabiano da Silva Alves ${ }^{2,3}$
}

Resumo. Cypella (Iridaceae): o que sabemos sobre a diversidade do gênero? Cypella é um gênero centrado nos Campos do sudeste da América do Sul, que pode ser reconhecido por suas flores com tépalas internas com uma área densa de tricomas glandulares localizados em uma depressão central, com ramos bem desenvolvidos, compactados, divididos em três cristas, duas delas agudas e posicionados na parte adaxial, e a outra crista é abaxial e exibe uma superfície estigmática transversal. É fornecida uma chave para distinguir Cypella e gêneros relacionados e uma tabela com as principais diferenças entre eles. Neste estudo são reconhecidas 31 espécies e cinco subespécies de Cypella: C. Alonsoana, C. amambaica, C. aquatilis, C. armosa, C. aurinegra, C. catharinensis, C. charruana, C. crenata, C. curuzupensis, C. discolor, C. exilis, C. fucata, C. gloriana, C. guttata, C. Hauthalii, C. Herbertii (subespécies Herbertii, brevicristata, reflexa e Wolffhuegelii), C. laeta, C. lapidosa, C. laxa, C. luteogibbosa, C. magnicristata, C. opalina (subespécies opalina e minuticristata), C. Osteniana, C. Pabstiana, C. parviflora, C. pusilla, C. Ravenniana, C. rivularis, C. suffusa, C. trimontina e C. uliginosa. São apresentados comentários sobre distribuição geográfica, afinidades taxonômicas e morfologia de todos os táxons, e foi organizada uma chave para distinguir as espécies de Cypella. São tratadas várias novidades taxonômicas, C. opalina é um novo status e combinação proposta, C. opalina subsp. minuticristata é uma nova combinação recomendada. É designado um neótipo para C. curuzupensis e lectótipos para $C$. lapidosa e $C$. opalina. Novos lectótipos são selecionados para C. Herbertii e C. laeta, sendo explicado o motivo da rejeição dos lectótipos escolhidos anteriormente para essas duas espécies. Ilustrações de C. Hauthalii, C. Herbertii e C. opalina, além de exsicatas do neótipo de C. curuzupensis são apresentadas. Os táxons C. boliviana, C. brasiliensis, C. geniculata, $C$. oreophila e $C$. unguiculata são excluídos do gênero, sendo comentado o posicionamento genérico destes táxons, enquanto $C$. craterantha, C. elegans e C. Herbertii subsp. reflexa $\mathrm{f}$. palmeti são considerados taxons duvidosos.

Palavras-chave: Iridaceae, gênero, diversidade, campos, América do Sul, Tigridieae.

\begin{abstract}
Cypella (Iridaceae): What do we know about the diversity of the genus? Cypella is a genus centered on the grasslands in Southeast South America, which can be recognized by its flowers with inner tepals having a dense area of glandular trichomes located in a central depression, style branches well developed, compressed, divided above in three crests, two of them acute and positioned in the adaxial part, and the other crest is abaxial and displays a transverse stigmatic surface. A key to distinguish Cypella and related genera is supplied and a table with the mainly differences among them. In this study are recognized 31 species and five subspecies of Cypella: C. Alonsoana, C. amambaica, C. aquatilis, C. armosa, C. aurinegra, C. catharinensis, C. charruana, C. crenata, C. curuzupensis, C. discolor, C. exilis, C. fucata, C. gloriana, C. guttata, C. Hauthalii, C. Herbertii (subspecies Herbertii, brevicristata, reflexa and Wolffhuegelii), C. laeta, C. lapidosa, C. laxa, C. luteogibbosa, C. magnicristata, C. opalina (subspecies opalina and minuticristata), C. Osteniana, C. Pabstiana, C. parviflora, C. pusilla, C. Ravenniana, C. rivularis, C. suffusa, C. trimontina, and C. uliginosa. Comments about geographic distribution, taxonomic affinities, and morphology of all taxa are presented, and a key to distinguish the species of Cypella was organized. Several taxonomic novelties are treated, C. opalina is a new status and combination proposed, C. opalina subsp. minuticristata is a new combination recommended. Is designated a neotype for $C$. curuzupensis and lectotypes are designated for C. lapidosa and C. opalina. New lectotypes for C. Herbertii and $C$. laeta are selected, explaining the reason for the rejection of the previously chosen lectotypes for these two species. Illustration of C. Hauthalii, C. Herbertii and C. opalina are showed, and exsiccates of the neotype of C. curuzupensis are presented. Furthermore, C. boliviana, C. brasiliensis, C. geniculata, C. oreophila and C. unguiculata are excluded of the genus, and the generic placement of them is commented, while C. craterantha, C. elegans and C. Herbertii subsp. reflexa f. palmeti are considered doubtful taxa.
\end{abstract}

Key Words: Iridaceae, genus, diversity, grasslands, South America, Tigridieae.

Accepted on June 4, 2020.

${ }^{1}$ Curso de Ciências da Natureza, Universidade Federal do Pampa, Rua 21 de abril 80, Dom Pedrito, Rio Grande do Sul, 96450-000. E-mail: deble.biol@gmail.com (author for correspondence)

${ }^{2}$ Curso de Ciências Biológicas, Universidade da Região da Campanha, Praça Getúlio Vargas 47, Alegrete, Rio Grande do Sul, 97542-570, Brazil. E-mail: alves.fs.bio@gmail.com

${ }^{3}$ Núcleo de Estudos Botânicos Balduíno Rambo, Universidade Federal de Santa Maria, Santa Maria, Rio Grande do Sul, 97105-900. 
The World Checklist of Iridaceae (WCI) (Barker, 2020) list Cypella with 38 species and five intraspecific taxa accept, and comprising, thereby, the largest genus of the tribe Tigridieae in South America. However, the number of valid species can range according to the different interpretations about generic limits of Cypella; for example, Roitman \& Castillo (2007), Goldblatt \& Manning (2008), and Roitman et al. (2008) give a broad definition to the genus, including Phalocallis Herbert, Kelissa Ravenna, and Onira Ravenna as subordinated to Cypella. On the other hand, Chauveau et al. (2012) evidenced this widely circumscribed Cypella as polyphyletic, and suggested Hesperoxiphion Baker, Larentia Klatt, and Phalocallis Herbert as segregated.

These instability in the generic boundaries of Cypella reflects in the list of the WCI, since the genus Phalocallis Herbert is treated as accept, but only $P$. coelestis (Lehm.) Ravenna is listed as valid, and Cypella boliviana Huaylla, Phalocallis geniculata (Klatt) Ravenna, and $P$. oreophila (Spegazzini) Ravenna, all these species morphologically related to $P$. coelestis are treated as accept names under Cypella (see Ravenna 2003a, Huaylla \& Wood 2012, Barker 2020). Another example, are the names Cypella Hauthalii and Herbertia Hauthalii, which are both treated as valid in the WCI. Even so, according to the generic delimitation of WCI, the genus Cypella is confined in South America, and its species are mostly restricted to subtropical grasslands in Southeastern of the continent (SESA grasslands, according to Azpiroz et al. 2012).

The genus Cypella includes small or medium-sized bulbous plants, with plicated leaves, and spathe containing two convolute valves, with outer valve having ca. $1 / 2$ or up to $2 / 3$ of total length of the inner valve, and inflorescence reduced to one or two flowers per spathe (Ravenna 2003b). The flowers are yellow, orange, white or more rarely lilac-bluish, with tepals whorls sharply dissimilar, being the inner tepals smaller, and with the blade having a complex arrangement tridimensional, and claws ascendant or patent.The outer tepals, in its turn, are often oblong, pandurate, and slightly patent or reflexed, with broadly clawed proximal portion, which form a central concavity with the claws of inner tepals (Ravenna 2003b, Goldblatt \& Manning 2008, Ravenna 2009, Deble et al. 2015a, Deble et al. 2015b).

Useful morphologic attributes to distinguish the genus in its narrow sense comprises a dense area of one-celled lipidic trichomes located in a central depression of the inner tepals, the style slender towards the base, with branches well developed at top, compressed, divided above in three crests, two of them acute and located in the adaxial part, and the other crest, positioned abaxially, displays a transverse stigmatic surface, while the stamens are erect or slightly reclined, with anthers having wide connective, and filaments obclavate or tapeshaped, fused, partially fused or totally free (Goldblatt \& Manning 2008, Deble \& Alves 2017b).

The taxonomic and nomenclatural difficulties of the genus Cypella are well known, which have led in many cases to a low degree in interpretation of species (Deble et al. 2015a, Deble \& Alves 2017a, Deble \& Alves 2017b, Deble 2017). The mainly problems are frequent for all Iridaceae, and are due the following aspects: few collections represented in herbaria, reduced number of flowers on dry material, particularly bad preservation of specimens, because the structure of perigone is lost during the drying process, and the absence of types of several names, resulting necessary the analyses of live specimens and typification of names (see Deble 2017, Munguía-Lino et al. 2017).

Due these facts, this paper not comprises a review of the genus Cypella, because the knowledge about this genus is still incomplete, even though we have working with Cypella over one decade, the number of new species described in the last ten years suggest that others undescribed taxa are waiting to be discovery; furthermore, delimitation of species boundaries, mainly based in morphologic/phylogenetic analyzes are necessary to better delimitation of closely related species (e.g. Cypella Herbertii (Herbert) Herbert/C. catharinensis Ravenna, C. Pabstiana Ravenna/ C. lapidosa Ravenna), and some species up to now were not found by us in the nature (e.g. $C$. amambaica Ravenna, C. curuzupensis Ravenna, C. Pabstiana Ravenna) and the description of floral morphology is inadequate when only have dry material (see Munguía-Lino et al. 2017).

Even so, during fieldworks performed in Argentina, Uruguay, Brazil, and Paraguay, a meaningful number of species previously described by others authors were found in the nature, and in many cases in the same place of the type, being possible an accurate analyses of these taxa, and a comparison of morphologic features, ecological data, geographic range, and taxonomic approach, in- 
cluding description of new taxa, new synonymies and typification of names (see Deble et al. 2012a, Deble et al. 2012b, Deble et al. 2012c, Deble et al. 2015a, Deble et al. 2015b, Deble \& Alves 2017a, Deble \& Alves 2017b, Deble 2017). This prospectus about Cypella comprises a preview of the review of the genus, and includes a checklist of valid names, synonymies, typifications, comments about geographic distribution, morphologic relationships, excluded species, a key to distinguish Cypella from its related genera, beyond a key for segregation of species and sections of the genus.

\section{Material and Methods}

To conduct this study, collections from wild populations of Cypella were performed in eastern and northeastern Argentina (Buenos Aires, Corrientes, Entre Ríos, and Misiones Provinces), part of center-west (Mato Grosso do Sul State), and southern Brazil (Paraná, Rio Grande do Sul, and Santa Catarina States), central and southern Paraguay, and all Uruguayan territory, between October 2010 and April 2020. Additionally were evaluated over 5,000 specimens of Cypella (including digital images) deposited in the following herbaria: B, CORD, CTES, HDCF, FCQ, FLOR, G, HAS, HBR, ICN, K, LIL, LP, MVHM, MVM, MVFA, MVJB, NY, P, PACA, PY, R, RB, SGO, S, SI, SP, and US (herbaria acronym follows Thiers 2020). Images in high resolution were consulted at Jstor Global Plants. The private herbarium of Pierfelice Ravenna is cited under the acronym "Herb. Rav.". Moreover, specimens of several species of Cypella and close related genera are also cultivated. The morphological data mentioned in the key is based on the examined material (including live specimens), and the terminology follows Goldblatt \& Manning (2008), Beentje (2010) and Munguía-Lino et al. (2017). For the Argentinian Provinces and Brazilian States cited in the text were utilized the following abbreviations: BA (= Buenos Aires), CH (= Chaco), CORD (= Córdoba), CR (=Corrientes), ER (= Entre Ríos), FR (= Formosa), MG (= Minas Gerais), MI (= Misiones), MS (= Mato Grosso do Sul), MT (= Mato Grosso), PR (= Paraná), RS (= Rio Grande do Sul), SC (= Santa Catarina), SF (= Santa Fé), and SP (= São Paulo). For the phytogeographic regions of the Southeast South American Grasslands (= SESA) and Río de La Plata Grasslands (= RPG) mentioned in the Table 1 , was utilized the geographic delimitation suggested by Soriano et al. (1992), Bilenca \& Miñarro (2004), and Azpiroz et al. (2012).

\section{Results and discussion}

The morphological comparison of the genera Cypella, Hesperoxiphion, Kelissa, Larentia, Oni$\mathrm{ra}$, and Phalocallis demonstrated several and relevant difference in bulbs and roots, basal leaves and leafy anatomy, spathes, and floral morphology, which are summarized in the Table 1. Chauveau et al. (2012) positioned Cypella, Kelissa and Oni$r a$ in "Tigridieae Clade B", while Hesperoxiphion and Phalocallis were placed in "Tigridieae Clade A". The morphologic attributes are in accordance with the molecular data obtained by Chauveau et al. (2012), in view of Hesperoxiphion and Phalocallis seem to be further away from Cypella than the others genera which are positioned in "Tigridieae Clade B", as Kelissa and Onira. Based in these molecular and also morphologic data, we considered segregated of Cypella the genera Hesperoxiphion, Kelissa, Larentia, Onira, and Phalocallis, and a key to distinguish them is proposed below. Comparatively, except by Cypella, all these genera or are monotypic or are composed by few species, occuring almost totally in South America. The number of accepted taxa is indicated in the key, after the name of the genus.

\section{Key to distinguish Cypella from others genera often placed under Cypella}

1. Style branches filiform, without crests, ending in a short stigmatic portion at top .................................................... 2

- Style branches crested, conduplicate, thicker than the style, stigmatic portion transverse to the adaxial crests ................. 3

2. Style columnar, hidden by the stamens; stamens with connected filaments, forming a column ... Kelissa Ravenna (monotypic)

- Style trifid, visible among the stamens; stamens with free filaments ......................................... Onira Ravenna (monotypic)

3. Inner tepals with long and abundant glandular trichomes on the blade .....

- Inner tepals without long glandular trichomes (or if present, few and scattered along the claws). Glandular trichomes onecelled, forming dense carpets in specific parts of the blade 
4. Flowers opening in the middle or late afternoon. Inner tepal blade with long glandular trichomes in a central stripe along the top. Style branches ending in three crests, two adaxial and one abaxial, crests not petaloid .. Hesperoxiphion Baker (5 species)

- Flowers opening in the morning. Inner tepal blade with glandular trichomes in two lateral bands along the top. Style branches ending in two rounded and petaloid crests Phalocallis Herbert (5 species)

5. Spathes with two plicate valves, subequal in length. Style branches with two crests Larentia Klatt (2 or 3 species)

- Spathes with two convolute valves, with outer valve having ca. $1 / 2$ or up to $2 / 3$ of total length of the inner valve. Style branches with three crests, two adaxial and one abaxial .....

Cypella Herbert (31 species)

\section{Description}

Cypella Herbert, Botanical Magazine 53: t. 2637 (text 2). 1826. Typus: Tigridia Herbertii Herbert, Botanical Magazine 52: t. 2599. 1825.

= Polia Tenore, Cat. Orto Bot. Napoli: 92. 1845. Typus: Polia bonariensis Tenore, Catalogo Orto Botanico di Napoli: 92. 1845. [nom. illeg.], non Polia Louriero (1790).

Small to medium sized perennials plants. Bulbs with darker cataphylls and roots fibrous persistent, not thickened. Stems nearly cylindrical or slightly angled, slender. Basal leaves at anthesis absent or few, plicate. Cauline leaf often present, and usually sheathing the stem, the upper leaves, if present, gradually smaller, and the most distal bracteiform at the base sheathing the basal part of the peduncles. Sinflorescence in rhipidium, branched or more rarely fasciculiform. Spathes herbaceous, pallid-green, bivalved, both valves convolute, one or two-flowered, often pedunculate; outer valve smaller than the inner valve. Pedicel filiform, usually of equal length of the spathe. Flowers radially simetrical, conspicuous, fugacious, yellow or white, rarely pallid lilac-blue, with the tepals forming one central concavity. Tepal whorls notably dissimilar. Outer tepals obovate-oblong or oblong, patent or reflexes, often panduriform, base clawed; claws cuneate, often with few glandular trichomes scattered. Inner tepals geniculate-recurved or ascendant-reflexes, slightly inclinate, then curved upward, blades with a central depression densely covered by a carpet of one-celled glandular trichomes, surrounded by a lateral high part; claws linear to cuneate, with glandular trichomes scattered. Staminal filaments tape shaped, obclavate or thickened in both ends, free or totally connected forming a conical column; connective broad, thecae often darker, pollen dark-grey, bluish-grey, ochraceous or yellow. Ovary oblong or obovate, 3-locular, with abundant ovules.
Style slender towards the base and thickened at top, ending in three conduplicate branches. Style branches channeled, attached for $1 / 2$ of total length or free, ending in three crests, two of them adaxial, and one abaxial, with a transverse stigmatic portion. Capsules obovate or oblong, containing many seeds. Seeds angular, often brown or reddish brown, with epidermis minutely faveolate, more rarely smooth or folded.

Geographic distribution and habitat - Majority of species growing on grasslands in Southern Brazil, Uruguay and northeast Argentina.

\section{Accepted species and sections}

Ravenna (1981a, 1981b, 2003b) was the first to note the existence of morphologic groups under Cypella, and proposed the segregation of the genus in three sections: Cypella, Nais, and Ionella. The first section includes Cypella Herbertii, the type of the genus, and its related species. The section Nais was described basis on the urceolate shape of the perigone and ascendant-reflexes inner tepals of $C$. aquatilis Ravenna, the type of the section, and more C. crenata (Vellozo) Ravenna, and C. pusilla (Ravenna 1981a), while the name Ionella, in its turn, was not validly published, and was created by Ravenna to encompass Cypella Hauthalii. The majority of the authors not accepted the segregation of the genus, due to recognition of Cypella as polyphyletic (see Goldblatt \& Manning 2008, Chauveau et al. 2012, Chauveau et al. 2014). Even so, the recognition of the sections Cypella and Nais was mentioned as useful to distinction morphologic of species (see Deble et al. 2015a, Deble et al. 2015b), and the section that belongs the listed species are indicated after the name, except for C. Hauthalii and C. opalina, which the taxonomic affinities and relationships are still few understood. 


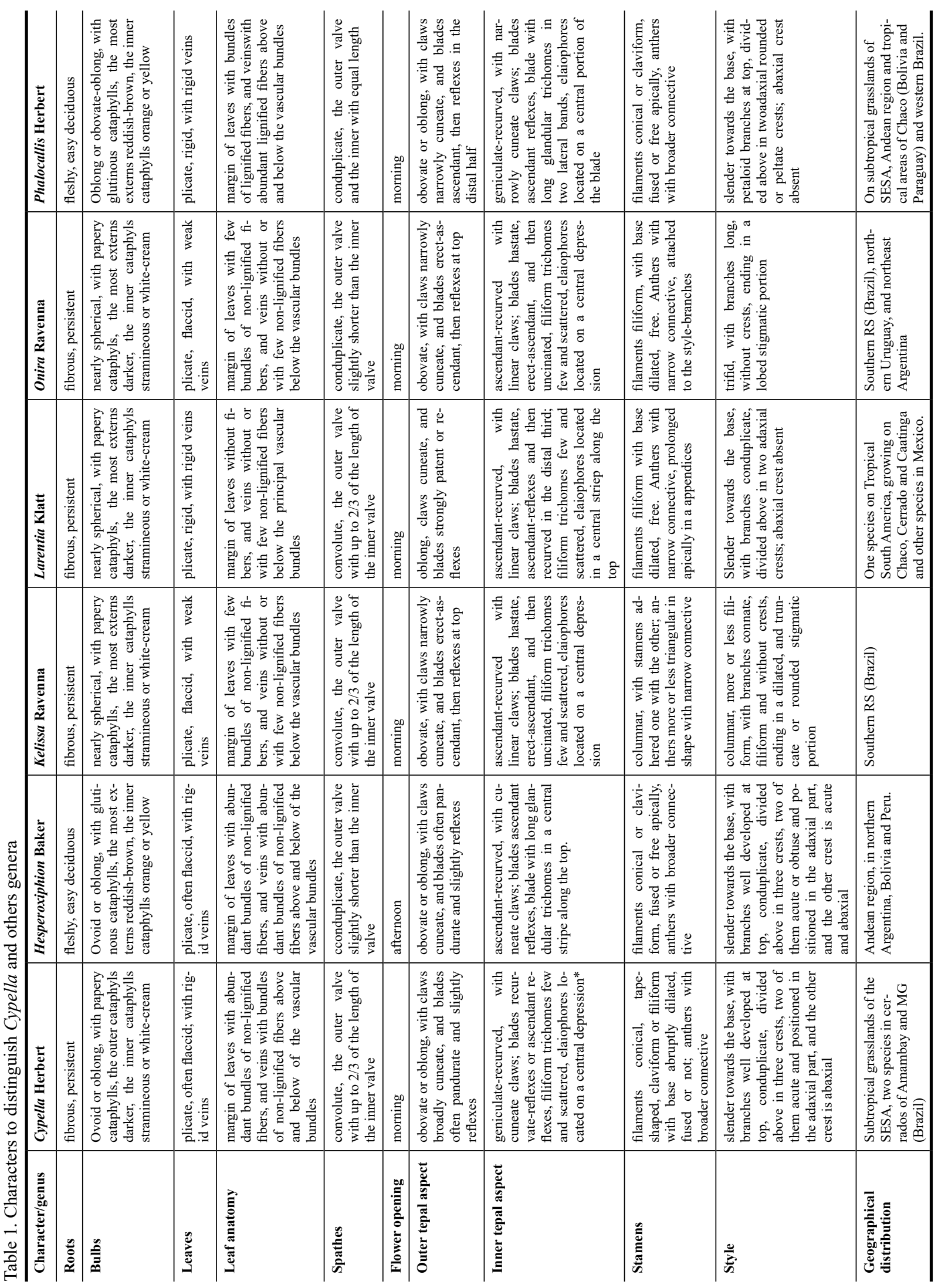




\section{Key to distinguish species and sections of Cypella}

1. Inner tepals with linear claws; blades hastate, erect-ascendant, and then uncinated ................................................... 2

- Inner tepals with cuneate claws; blades not hastate, recurvate-reflexes or ascendant reflexes .......................................... 4

2. Flowers pallid lilac-blue. Outer tepals ascendant in proximal half; inner tepals longer than the central concavity. Style (including style branches and crests) $18-23 \mathrm{~mm}$ long

C. Hauthalii

- Flowers white or bluish-white. Outer tepals almost erect in proximal half; inner tepals shorter than the central concavity. Style (including style branches and crests) $13-17 \mathrm{~mm}$ long

3. Crests of style branches $2.5-5 \mathrm{~mm}$ long C. opalina subsp. opalina

- Crests of style branches obsolete or up to $2 \mathrm{~mm}$ long C. opalina subsp. minuticristata

4. Inner tepals claws shorter than the blades. Lipid trichomes spreading in a central strep towards the basis of a central depression (sect. Cypella)

- Inner tepals claws longer than the blades. Lipid trichomes spreading on top of a central depression (except C. curuzupensis and C. uliginosa, which the trichomes spreading at the bottom of a central fold) (sect. Nais) ....................................... 23

5. Spathes two-flowered

- Spathes one-flowered 7

6. Plants delicate, up to $35 \mathrm{~cm}$ high. Spathes $1.9-2.8 \times 0.3-0.4 \mathrm{~cm}$. Flowers white, central concavity 10-15 mm diameter .....

C. Osteniana

- Plants robust, 38-90 cm high. Spathes 3.1-4.5 × 0.4-0.6 cm. Flowers golden yellow or orange, central concavity 18-23 mm diameter

C. Alonsoana

7. Filaments thickened, forming a conical column, slightly inclined, narrowed at the top (the filaments can be attached or free, being separated by a narrow cleft). Style often purplish in distal half; style branches with transverse stigmatic surface of the abaxial crest extending one in the each other crest

- Filaments obclavate, tape shaped or thickened in both ends, not forming a column, erect or porrect at the top (the filaments can be attached in the proximal half, being distinctly separated at the top). Style often yellow or orange in the distal half; style branches with transverse stigmatic surface of the abaxial crest separated one in the each other crest (except $C$. fucata) ...

8. Basal leaves elliptic-lanceolate, $25-45 \times 1.5-2.5 \mathrm{~cm}$, blades firm in tc more than $10 \mathrm{~mm}$ deep; anthers as long as the filaments

C. catharinensis

- Basal leaves linear to narrowly elliptic-lanceolate $25-75 \times 0.2-1.5 \mathrm{~cm}$, blades flexible, acute at the top; flowers with central depression less than $10 \mathrm{~mm}$ deep; anthers more long than the filaments (subequal in C. herbertii subsp. brevicristata)......

9. Flowers golden-yellow, orange or pallid-orange, $45-55 \mathrm{~mm}$ diameter. Crests of style branch more than $2 \mathrm{~mm}$ long, stigmatic area dark-purple

- Flowers yellow, up to $40 \mathrm{~mm}$ diameter. Crests of style branch up to $2 \mathrm{~mm}$ long, stigmatic area yellowish..... 10

10.Plants robust, up to $170 \mathrm{~cm}$ high. Bulbous 25-35 $\times 20-30 \mathrm{~mm}$, cataphylls straw-colored

- Plants more delicate, rarely more than $80 \mathrm{~cm}$ high. Bulbous 12-20 × 10-20 mm, cataphylls dark-brown

C. Herbertii subsp. Herbertii

11.Outer tepals patent. Stamens with anthers and filaments subequal in length. Crests of style branch less than $1 \mathrm{~mm}$ long.

C. Herbertii subsp. brevicristata

- Outer tepals reflexed and twisted, often purplish-brown spotted along the blade. Stamens with anthers more long than the filaments. Crests of style branch 1-2 mm long

12.Staminal filaments tape-shaped, at the base gradually wider C. Herbertii subsp. reflexa

- Staminal filaments obclavate or thickened in both ends, at the base abruptly dilated

13. Flowers orange, with central concavity painted with red-brown spots. Plants growing on fast-flowing water ............ $C .15$

13.Flowers orange, with central concavity painted with red-brown spots. Plants growing on fast-flowing water .......... C. guttata

- Flowers yellow, with central concavity with a purple-brown stain in the proximal part ..................................................... 14

14.Leaves elliptic-lanceolate, $0.4-1.5 \mathrm{~cm}$ width. Spathes $1.4-2.6 \times 0.3-0.4 \mathrm{~cm}$. Plants growing on banks of rivers subject to flooding

- Leaves narrowly linear, $1.5-2 \mathrm{~mm}$ width. Spathes $4-4.5$ x 0.2-0.3 cm. Plants growing on dry grasslands C. parviflora

15.Anthers less than $5 \mathrm{~mm}$ long. Style branches $2.4-4 \mathrm{~mm}$ long

C. Pabstiana

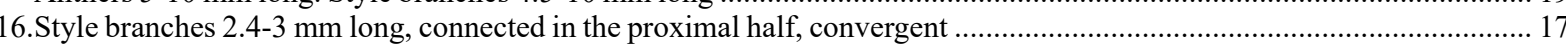

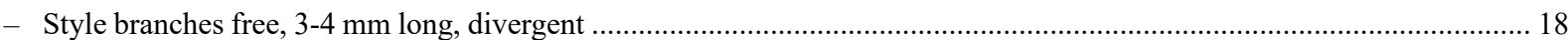

17.Grasslands and stony grasslands in southern Brazil, northeast Argentina and Uruguay. Outer tepals with veins darker than

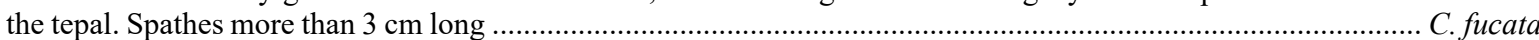

- Grasslands and wet grasslands in Amambay, Paraguay. Outer tepals with veins of the same color of the tepal. Spathes less than $3 \mathrm{~cm}$ long 
18.Flowers white; blades markedly recurved; stamens with connective less than $1 \mathrm{~mm}$ width; Pollen grayish-blue; seeds with epidermis shaped like a honeycomb C. luteogibbosa

- Flowers yellow, outer tepals stained with dark-purple in the base of the blade; blades slightly patent; stamens with connective more than $1 \mathrm{~mm}$ width. Pollen ochraceous-yellow. Seeds with epidermis smooth ..................................... C. aurinegra

19.Flowers with central depression densely painted with red-brown spots. Inner tepals $22-24 \times 15-16 \mathrm{~mm}$....... C. magnicristata

- Flowers with central depression with purple stripes or macules in the proximal third. Inner tepals $10-18 \times 7-12 \mathrm{~mm} \ldots \ldots \ldots .20$

20.Flowers orange, often with a central macula extend longitudinally along the blade. Abaxial crest of style margin entire .......... C. exilis

- Flowers often yellow (rarely dull-orange), blades without macula. Abaxial crest of style margin fimbriate ..... 21

21.Inner tepal claws narrowly cuneate, measuring $1.8-2.3 \mathrm{~mm}$ width in proximal portion, and $3.5-5 \mathrm{~mm}$ in distal portion

C. armosa

- Inner tepal claws broadly cuneate, measuring $1.8-2.4 \mathrm{~mm}$ width in proximal portion, and $8-10 \mathrm{~mm}$ in distal portion ........ 22

22. Style branches 7-9 $\mathrm{mm}$. Filaments $4-5 \mathrm{~mm}$ long

C. trimontina

- Style branches 4.5-6.5 mm. Filaments 2.5-4 mm long

C. lapidosa

23. Spathes two-flowered 24

- Spathes one-flowered ............................. 26

24.Basal leaves 10-25 mm broad, often obtuse. Spathes 25-35 mm long. Plants growing on fast-flowing water ........ C. aquatilis

- Basal leaves 1-6 mm broad, often acute. Spathes 33-45 mm long. Plants growing on grasslands

25

25.Flowers ochraceous-yellow, veins dark. Spathes 2-4 per branch. Inner tepal blades with dark ochraceous glandular trichomes surrounded by abundant, oblique dark-purple stripes. Filaments free, slightly porrect

C. laeta

- Flowers golden-yellow, veins yellow. Spathes 1-2 per branch. Inner tepal blades with yellowish glandular trichomes surrounded by few, oblique purples stripes. Filaments adhered to style in the proximal half

26. Outer tepals abruptly clawed, distal part of the claw 4-5 mm wide, Outer and inner tepal claws similar in shape and size. Filaments 8.4-10.5 mm long. Anthers 8-9.5 mm long

C. charruana

- Outer tepals merely clawed, distal part of the claw 6-11 mm wide. Inner tepal claws much narrower than the outer tepal

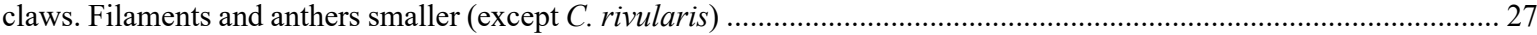

27. Spathes with peduncles (1) $2.5-11 \mathrm{~cm}$ long. Plants growing on bogs, along streams, bulbs developed in most soils ........... 28

- Spathes sessile or peduncles up to $2.5 \mathrm{~cm}$ long. Plants growing on grasslands or rocks, bulbs developed in dry soils .......... 32

28. Outer and inner tepals brown spotted. Filaments $6.4-9.3 \mathrm{~mm}$ long

C. rivularis

- Outer tepals not spotted. Inner tepals with reddish-brown spots, sometimes absent or scarce. Filaments 2.8-6 mm long .... 29

29.Inner tepals patent-geniculate, deeply folded, glandular trichomes scattered at the bottom of the fold ............................. 30

- Inner tepals arcuate-recurved, not folded, glandular trichomes on the top of the blade .................................................... 31

30. Plants 50-120 cm high. Spathes per branch 2-5, peduncle of the spathes $3.5-9.4 \mathrm{~cm}$ long. Filaments $3-4 \mathrm{~mm}$ long, up to $1 / 2$ the length of the anthers

C. uliginosa

- Plants 25-50 cm high. Spathes per branch 1-2, peduncle of the spathes 1-4.5 cm long. Filaments 5.5-6 mm long, as long as the anthers

C. curuzupensis

31.Flowers orange, blades firm in texture. Inner tepals 22-28 × 7.5-10 mm. Southern Minas Gerais, Brazil

.. C. crenata

- Flowers yellow, blades thin. Inner tepals 16-20 × 11-15 mm. Southern Paraguay, northeastern Argentina, and Brazil (RS, $\mathrm{SC}, \mathrm{PR}, \mathrm{SP}, \mathrm{MS}$ )

C. laxa

32. Spathes densely pruinose. Flowers white or ochraceous-white. Outer tepals purplish-brown veined

C. discolor

- Spathes non pruinose or scarcely pruinose. Flowers yellow. Outer tepals yellow or orange veined .................................... 33

33. Sinflorescence fasciculiform. Spathes $2.2-3 \times 0.2-0.3 \mathrm{~cm}$, sessile or almost sessile (peduncles up to $8 \mathrm{~mm}$ ). Perigone 23-40 mm diameter

... 34

- Sinflorescence branched. Spathes 3.6-4.8 $\times$ 0.3-0.5, pedunculate, peduncles 5-18 mm long. Perigone 38-55 mm diameter .....

34.Inner tepals 6-7 mm width, glandular trichomes spreading on a small area, 1.5-2.5 mm width. Filaments 4.5-5 mm long ........ C. gloriana

- Inner tepals 8-9 mm width, glandular trichomes spreading on a broad area, 4-5 mm width. Filaments 5.5-6.5 mm long

C. pusilla

\section{List of species}

Cypella Alonsoana Deble \& F. S. Alves, Kew Bulletin 72 (3) 41: 2.2017 (sect. Cypella). Typus: URUGUAY. Tacuarembó: Valle Eden, 24.X.2015 7(fl, fr), L. P. Deble \& A. S. de Oliveira 15626 (holotypus SI!, isotypi CTES!, ICN, K, MVFA!, PACA!). Figure 1A.

Geographic distribution and habitat - North Uruguay. Cypella Alonsoana occurs in the high parts of the ridge of the geomorphologic unit 
"Cuesta do Haedo" (see Deble \& Alves 2017b) in the localities of Valle Éden, eastern Tacuarembó Department, and Cuchilla Negra, western Rivera Department. The specimens occur in slope of hills, in well-drained soils, associate with shrubs and small trees, which compound the vegetation of "Serranias".

Comments - C. Alonsoana is easily segregated of others species by its robust habit, two-flowered spathes, and golden-yellow flowers. Within the sect. Cypella, two-flowered spathes are found also in $C$. Osteniana, but the latter can be easily identified by its smaller flowers and white perigone.

Cypella amambaica Ravenna, Onira Botanical leaflets 12 (1): 4. 2009 (sect. Cypella). Typus: PARAGUAY. Amambay: Parque Nacional Cerro Corá, "al pie del cerro Guaiguy Hog", 3.X.1980 (fl), J. Fernandez-Casas 4012 (holotypus G [G00038393 image seen!]).

Geographic distribution and habitat- Eastern Paraguay (Amambay Department). Cypella amambaica probably grows on sandy soils in the savannahs at the base of the hill locally designated Guaiguy Hog.

Comments - During botanic expeditions performed in the place indicated in the holotype, $C$. amambaica was not found, suggesting the rarity of this species. The analyses of the holotype of $C$. amambaica evidences this species as morphologically similar to $C$. lapidosa Ravenna, but additional data are not possible due the few floral parts of the single material known.

Cypella aquatilis Ravenna, Nordic J. Bot. 1: 489. 1981 (sect. Nais). Typus: BRAZIL. Rio Grande do Sul: Vacaria, "culta in Bonaria ex bulbis in rivulo ad Faz. da Ronda pr. Vacaria civit. Rio Grande do Sul Brasiliae collectis" I.1970, P. F. Ravenna 1037 (holotypus: Herb. Rav. not localized; isotypus: RB, not localized). Lectotypus (designated by Eggers et al. 2019: 748): BRAZIL. Rio Grande do Sul: Vacaria, "fazenda da Ronda, per Vacaria", 3.I.1947, B. Rambo s.n. (lectotypus PACA [PACA 34747!]). Figure 1B.

Geographic distribution and habitat - Southern Brazil (Central and Northern RS, SC, PR) and northeast Argentina (MI). Cypella aquatilis is one of the more adapted species of the genus at aquatic environmental, since this species occur exclusively on streams and rivers of fast flowing water.

Comments - C. aquatilis is easily identified by its wider and flaccid leaves, and shorter and thickened spathes, containing two flowers. In its geographic range of occurrence is the single species of sect. Nais that occurs on fast flowing water; the others species of this section with similar habitat occurs in southern RS State and northern Uruguay.

Cypella armosa Ravenna, Wrightia 7 (1): 20. 1981. Typus: PARAGUAY. Paraguarí: San Bernardino, "in herbosis inundatis pr. San Bernardino, Paraguariae" 17.II.1966, P. F. Ravenna 462 (holotypus: Herb. Rav., not localized). Lectotypus (designated by Eggers et al. 2019: 748): PARAGUAY. Paraguarí: San Bernardino, "in herbosis inundatis pr. San Bernardino, Paraguariae" 17.II.1966, P. F. Ravenna 462 (lectotypus K [K000322476 image seen!]). Figure 1C.

= Cypella gracilis (Klatt) Baker f. humilis Baker, Bulletin de l'Herbier Boissier 2 (3): 1102. 1903. Lectotypus (designated by Deble 2017: 28): PARAGUAY. Depto Central: Ypacaray, "in campis humidis pr. lacu Ypacaray, Sept." E. Hassler 1703 (lectotypus P [P02061541 image seen!]).

Geographic distribution and habitat - Southern and eastern Paraguay, northeast Argentina $(\mathrm{CH}$, CR, ER, FR, MI, SF) and western RS State, Brazil. The specimens occur on bogs or periodically inundated grasslands.

Comments - C. armosa is morphologically similar to $C$. exilis; however, differs by its inner tepals with narrowly cuneate claws, style with longer and declined style branches, and staminal filaments shorter and thickened in both ends. The perigone color is also useful to distinguish $C$. armosa and $C$. exilis, since $C$. armosa displays often yellow perigone (vs. orange, often with a central macula extending longitudinally along the blade of the outer tepal in C. exilis).

Cypella aurinegra Deble \& A. González, Phytotaxa 236: 102. 2015 (sect. Cypella). Typus: URUGUAY. Cerro Largo: Cañada Yerba Sola, "11 km al norte de Puntas del Parao", 32 $32^{\circ}$ ' $36^{\prime \prime} \mathrm{S}$ and 54 22' 51" W, 7.IV.2014 (fl.), A. González 2250 (holotypus MVFA!). Figura 1D.

Geographic distribution and habitat- This species is micro-endemic in the sources of Tacuarí River, Southern Cerro Largo Department, Eastern Uruguay. Individuals grow in wet grasslands close to the sources, in moist and usually deep soil above sandstone of the "Tres Islas" geological formation, Lower Permian.

Comments - C. aurinegra is morphologically 

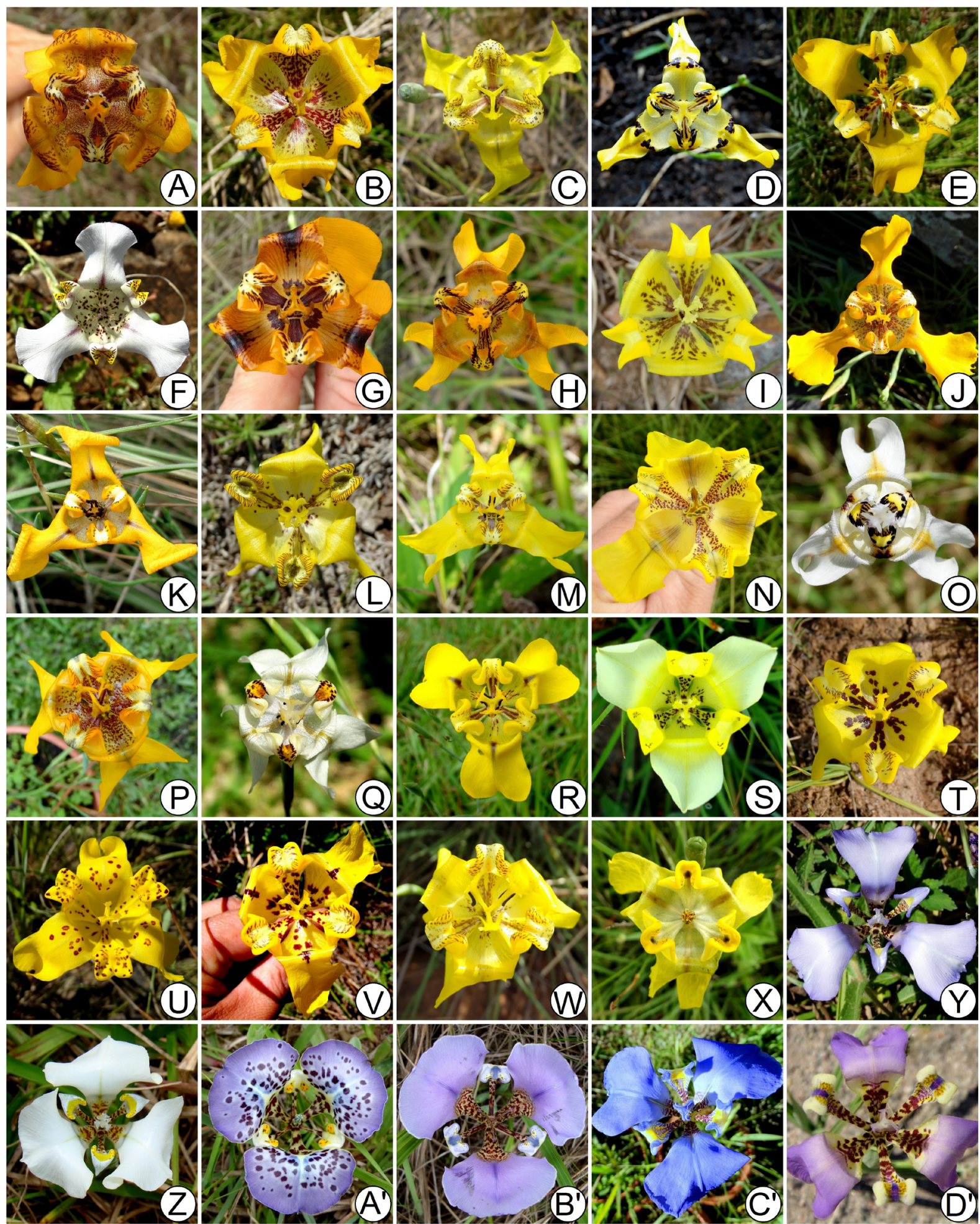

Figure 1. Diversity of flowers in Cypella (A-Z) and related genera (A'-D'). A, C. Alonsoana. B, C. aquatilis. C, C. armosa. D, C. aurinegra. E, C. charruana. F, C. discolor. G, C. exilis. H, C. fucata. I. C. gloriana. J, C. guttata. K, C. Herbertii subsp. reflexa. L, C. laeta. M, C. lapidosa. N, C. laxa. O, C. luteogibbosa. P, C. magnicristata. Q, C. Osteniana. R, C. parviflora. S, C. pusilla. T, C. Ravenniana. U, C. rivularis. V, C. suffusa. W, C. trimontina. X, C. uliginosa. Y, C. Hauthalii. Z, C. opalina subsp. opalina. A', Kelissa brasiliensis. B', Onira unguiculata. C', Phalocallis geniculata. D', Phalocallis oreophila. 
similar to C. fucata and C. luteogibbosa; however, differs from both species by its yellow flowers with dark-purple stains, and seeds with smooth epidermis.

Cypella catharinensis Ravenna, Onira Botanical leaflets 10 (13): 39. 2005 (sect. Cypella).Typus: BRAZIL. Santa Catarina: São Joaquim, "camino frente al Horto de Floricultura" 14.XII.1971 (fl, fr), A. Lourteig 2180 (holotypus BAB [BAB00000505 image seen!], isotypi CTES [CTES60579!], P [P02061537 image seen!], NY [NY00507612 image seen!]).

Geographic distribution and habitat - Cypella catharinensis seemingly is restrict to stony grasslands, along streams at altitudes between 1,000 and 1,400 m a.s.l., in southeast SC State, Brazil.

Comments - C. catharinensis is morphologically similar to $C$. Herbertii; however, can be distinguished by its leaves wider and rigid, smaller anthers, and more deep central concavity of perigone. Observation - Eggers et al. (2019) considered $C$. catharinensis as a synonym of $C$. Herbertii subsp. Herbertii. We prefer to keep the species as segregated due to the rigid and broad leaves, at apex obtuse, shape of the staminal filaments and style crests, and smaller fruits, having seeds with smooth epidermis. All these morphologic aspects resemble $C$. Herbertii subsp. Wolffhuegelii, one subspecies endemic in southern BA province (Argentina). The specific ranking of $C$. catharinensis requires additional studies and before that we prefer to keep the species as independent.

Cypella charruana Deble \& F. S. Alves, Darwiniana, nueva serie, 3(2): 237. 2015 (sect. Nais). Typus: BRAZIL. Rio Grande do Sul: Santana do Livramento, on the border with Uruguay, in the spring of the Quaraí River, in the midst of native grassland in moist soil on volcanic rock from the Serra Geral geological formation, $30^{\circ} 57^{\prime} 44.34$ "' S, 55 43' 33.68' W, 15.XI.2014 (fl, fr), L. P. Deble, A. S. de Oliveira-Deble \& F. S. Alves 15108 (holotypus SI!, isotypi MVFA!, PACA!). Figure $1 \mathrm{E}$.

Geographic distribution and habitat - Border between northern Uruguay and southern RS State, Brazil. Specimens occur on wet grasslands, sources and streams of the Basin of Quaraí River.

Comments - C. charruana is easily identified from its related species by the abruptly clawed outer tepals, and longer style and stamens.
Cypella crenata (Vellozo) Ravenna, Bol. Soc. Argent. Bot. 10 (4): 312. 1965. Bas.: Sisyrinchium crenatum Vellozo, Fl. Fluminensis 9: pl. 67. 1827 [1831]. Lectotypus (designated by Egger et al. 2019: 752): Original plate of Flora fluminensis in the Manuscript Section of the Biblioteca Nacional, Rio de Janeiro [cat. no.: mss 1198658 071] and later published in Vellozo, Fl. Flumin. Icones 9: tab. 67. 1831. Epitypus (designated by Eggers et al. 2019: 752): BRAZIL. Minas Gerais: Caldas, 22.XI.1874, A.F. Regnell-C.W.H. Mosén III 1216 (epitypus S [S-12-16048 image seen!], isoepitypus $\mathrm{S}$ [S-12-16047 image seen!]).

三 Cypella paludosa Klatt, Abhandl. Naturf. Gellesch. Un. Halle. 12: 365. 1882. $\equiv$ Phallocalis paludosa (Klatt) Kuntze, Rev. Gen. Pl. 1891. Typus: BRAZIL. Minas Gerais: Caldas, 18.II.1876, A.F. Regnell - C.W.H. Mosén III 1216 (holotypus $\mathrm{S}$ [two sheets, S12-16047 and S12-16048 image seen!], isotypus P [P02061538 image seen!]).

Geographic distribution and habitat - Southern MG State, Brazil. Specimens occur on bogs among areas of "campos de altitude".

Comments - C. crenata is morphologically similar to $C$. laxa, being very difficult to be distinguished based on exsiccates, since both species have the same morphologic attributes. However, according Ravenna (1981b), C. crenata differs of $C$. laxa by its orange perigone, tepals blade firm in texture, and style with longer and reclined branches; furthermore, both species have distinct geographic range, since C. laxa spreads in southern Brazil, northeast Argentina and southern and eastern Paraguay, while C. crenata is endemic in southern MG, distant ca. of $300 \mathrm{~km}$ of the nearest populations of $C$. laxa located in souther SP State (additional comments see below $C$. laxa).

Cypella curuzupensis Ravenna, Wrightia 7 (1): 19. 1981 (sect. Nais). Typus: PARAGUAY. Guairá: Villa Rica, "In paludibus pr. Curuzupe (ante Mbubevo), Villa-Ricae, Paraguariae", II.1966, $P$. F. Ravenna 463 (Herb. Rav., not localized). Neotypus (designated here): PARAGUAY. Guairá: Villa Rica, "Trayecto a cerro Tororo, Cordillera del Ybityrusu. En esteros, vegetación palustre" 20.IV.1999, F. Mereles \& M. Soloaga 7539 (neotypus FCQ [FCQ0038133!], isoneotypus FCQ [FCQ0037895!]). Figure 2A, B.

Geographic distribution and habitat - Guairá, southern Paraguay. Specimens occur on bogs and wet grasslands.

Comments - C. curuzupensis is easily identified from its related species by its reduced habit, and 
inner tepals patent-geniculate, deeply folded, having glandular trichomes scattered at the bottom of the fold. During fieldworks in February 2014 in Guairá, Paraguay, this species was not found in the wild, suggesting its rarity.

Typification- Ravenna (1981b) described $C$. curuzupensis having as base two collections, one of them performed by himself and designated as type, which was deposited in his private herbarium (about the necessity of typification of the types deposited in the private herbarium of Ravenna see Deble \& Alves 2017a, 2017b); while, the other material mentioned in the protologue was the collection Jorgensen 3871, which was examined in the herbaria BAB and SI; however, both paratypes

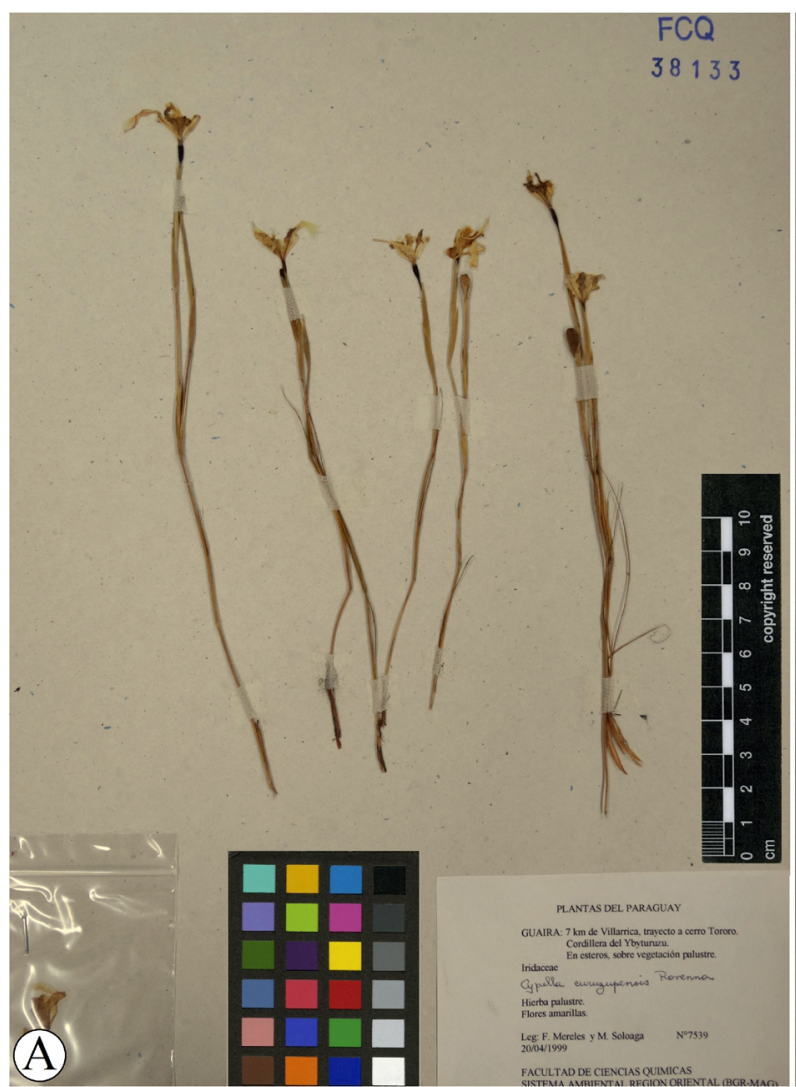

(B)

are incomplete, and not display flowers; furthermore, are mixed with others species, resulting impossible to prove if really some fragment belongs to $C$. curuzupensis, since in the same area occurs others species of Iridaceae, which shows similar vegetative habit, and we suspect that the material Jorgensen 3871 is C. armosa. Fortunately, during the analyses of exsiccates at FCQ herbarium, was examined the collection Mereles \& Soloaga 7539, which was collected near to place indicated in the protologue of $C$. curuzupensis (according to information provided by Lídia Perez Molas), and displays several flowers and morphologic attributes in accordance to original description of C. curuzupensis, being selected as neotype.

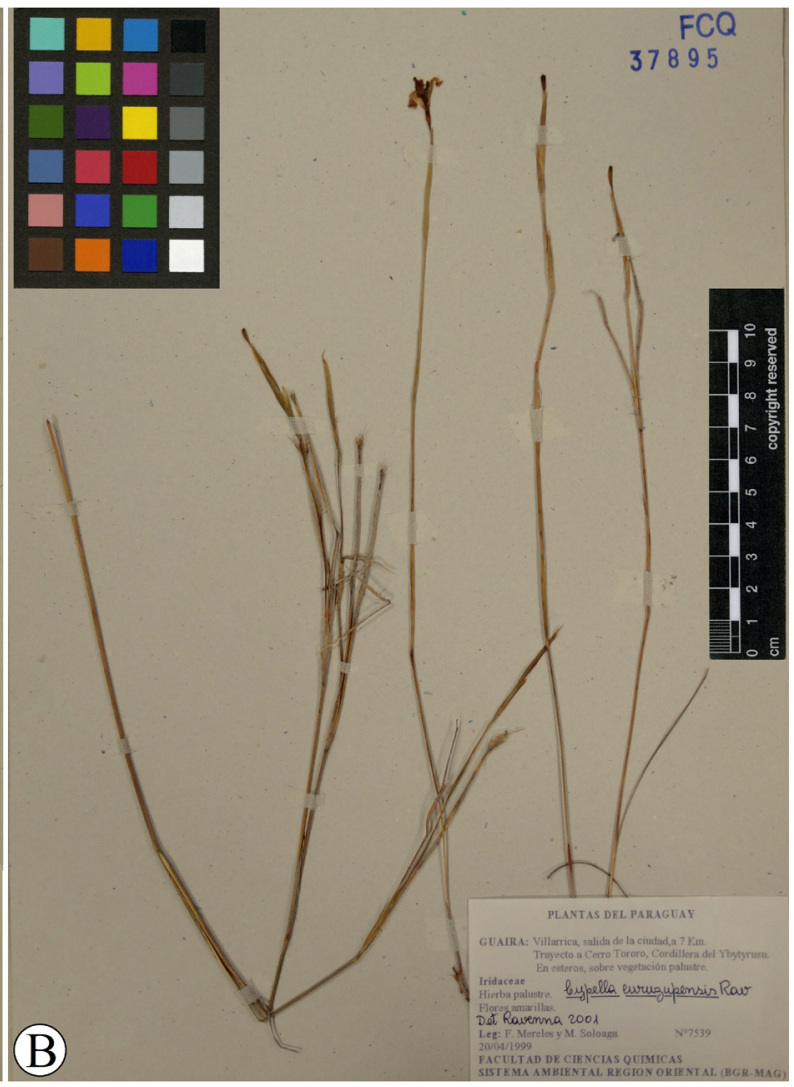

Figure 2. Cypella curuzupensis. A, neotypus from FCQ [FCQ0038133]. B, isoneotypus from FCQ [FCQ0037895].

Cypella discolor Ravenna, Wrightia 7 (1): 16. 1981 (sect. Nais). Typus: BRAZIL. Rio Grande do Sul: Quaraí, "culta in Bonaria ex bulbis ad Passo da Guarda civit, Rio Grande do Sul, Brasiliae collectis" XII.1967, P. F. Ravenna 507 (Herb. Rav., probably lost). Neotypus (Designated by Deble \& Alves 2017b: 51): BRAZIL. Rio Grande do Sul: Quaraí, na localidade do Passo da Guarda, em campo rupestre, [30¹8'21.22”S 55 58'03.58'W], 16.XII.2010, L. P. Deble \& A. S. Oliveira 12901 (holotypus SI!, isoneotypus CTES!, K). Figure 1F. Geographic distribution and habitat- RS State, Brazil, and Artigas Department, Northern Uruguay. Specimens occur on stony grasslands and shallow grasslands developed often on volcanic rocks. 
Comments-C. discolor is easily identified from its related species by its white-flowers and pruinose spathes. Despite its morphologic peculiarities, this species can be confused often in dry material with $C$. Ravenniana, but can be distinguished mainly by its pruinose spathes, flowers white or ocraceous-white, with outer tepals having darker veins (visible even on dry material), and different shape of inner tepals.

Cypella exilis Ravenna, Nordic J. Bot. 1: 492. 1981 (sect. Cypella). $\equiv$ Polia gracilis Klatt, Linnaea 31: 545.1862. Cypella gracilis (Klatt) Baker, J. Linn. Soc. Bot. 16: 129. 1877 [non Klatt 1862 [comb. illeg.]. $\equiv$ Sphenostigma gracile (Klatt) Benth. \& Hook. f., Gen. Pl. 3 (2): 695. 1883. $\equiv$ Phalocallis gracilis (Klatt) Kuntze, Rev. Gen. P1. 2: 702. 1891. Lectotypus (designated by Deble \& Alves 2017b: 54): BRAZIL/URUGUAY. "Habit. Brasilia meridionalis, Montevideo", II-III.1824, F. Sellow d2077. Following Urban (1893: 196) the local of collection was "emenda zum Yaceguay [=Acegua], über Herval, Serra dos Tapes, nach S. Francisco de Paula [= Pelotas]" (lectotypus B[B0366320 leftmost specimen!]). Figure 1G.

= Cypella amplimaculata Chauveau \& L. Eggers, Phytotaxa 174 (1): 29. 2014. Typus: BRAZIL. Rio Grande do Sul: Piratini, BR 293, direção Bagé, 140 m" 25.X.2011, A. M. Aita 49 (Holotypus ICN180155!).

Geographic distribution and habitat - A common species spreading in northern and eastern Uruguay and southern Brazil (RS and SC). Specimens occur mainly on grasslands and slope of hills, but also on wet grasslands and streams.

Comments - C. exilis is similar to C. armosa and C. lapidosa but can be distinguished by its flowers with orange perigone, often with a central macula extend longitudinally along the outer blade (visible even in dry material), and abaxial crest of style branch with margin entire (see additional comments in Deble 2017).

Observation - Eggers et al. (2019) recognized C. amplimaculata as a segregated taxon, and considered $C$. exilis as a doubtful species. However, the morphological characteristics of the type of $C$. exilis, which has a complete flower, let no doubt about the identity of this species.

Cypella fucata Ravenna, Wrightia 7 (1): 18.1981 (sect. Cypella). Typus: BRAZIL. Rio Grande do Sul: Caçapava do Sul, "culta in Bonaria ex bulbis ad pedem collis ubi Gruta do Segredo est pr. Caca- pava civit Rio Grande do Sul Brasiliae" XII.1965, P. F. Ravenna 500 (Herb. Rav., not localized). Neotypus (designated by Deble \& Alves 2017b: 52): BRAZIL. Rio Grande do Sul: Caçapava do Sul, "caminho para a gruta do segredo", 23.XII.2009, L. P. Deble \& A. S. de Oliveira-Deble 11032 (Neotypus SI!, isoneotypi CTES!, K). Figure $1 \mathrm{H}$.

= Cypella Osteniana Beauv. subsp. aurantiaca Roitman \& J. A. Castillo, Bol. Soc. Argent. Bot. 38 (3-4): 337. 2003. Typus: ARGENTINA. Corrientes: "Dep. Monte Caseros, cercanías de Tres Bocas" 16.IV.2003, Roitman \& Tourn s.n. (holotype BAB not seen).

= Cypella aprica Arechavaleta [nom. nud.]

Geographic distribution and habitat - C. fucata is one of the most common species of the genus, occurring on dry grasslands and rocky places in RS State, Brazil, almost all Uruguayan territory, and northeast Argentina (CR, ER).

Comments - C. fucata can be easily identified by a combination of the following features: small size and dull-orange flowers, with outer tepals dark-veined, and style having style branches convergent, very short and often fused by until $1 / 2$ of total length.

Cypella gloriana Deble \& F. S. Alves, Darwiniana, nueva serie, 3(2): 241. 2015 (sect. Nais). Typus: BRAZIL. Rio Grande do Sul: São Vicente do Sul, Cerro da Glória, "at the base of the hill in the northern flank, native grasslands on place of soil

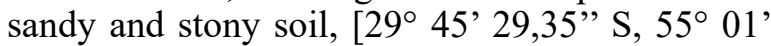
43,07” W], 25.X.2014 (fl., fr.), L. P. Deble, F. S. Alves \& M. I. P. Deble 15034 (holotypus SI!, isotypi MVFA!, PACA!). Figure 1I.

Geographic distribution and habitat - Micro-endemic in center-western RS State, Brazil. Specimens occur on stony grasslands at the base of the hill locally designated "Cerro da Glória".

Comments-C. gloriana is closely related to $C$. pusilla, but can be distinguished by the following attributes: bigger perigone, outer tepals with narrowed claws, inner tepals with blades markedly narrowed, and longer upwards, having lipidic trichomes spreading in a small area, stamens shorter, with porrect filaments, smaller anthers, and broader connective.

Observation - Cypella gloriana was recently merged in C. pusilla, based on molecular and morphological characteristics (Pastori et al. 2018). Beyond of the characters mentioned above, the shape of the perigone and the carpet of lipidic trichomes are diagnostic for the recognition of the species, which is why we maintain C. gloriana as separate. 
Deble, L.P. \& F.S. Alves, Cypella: What do we know?

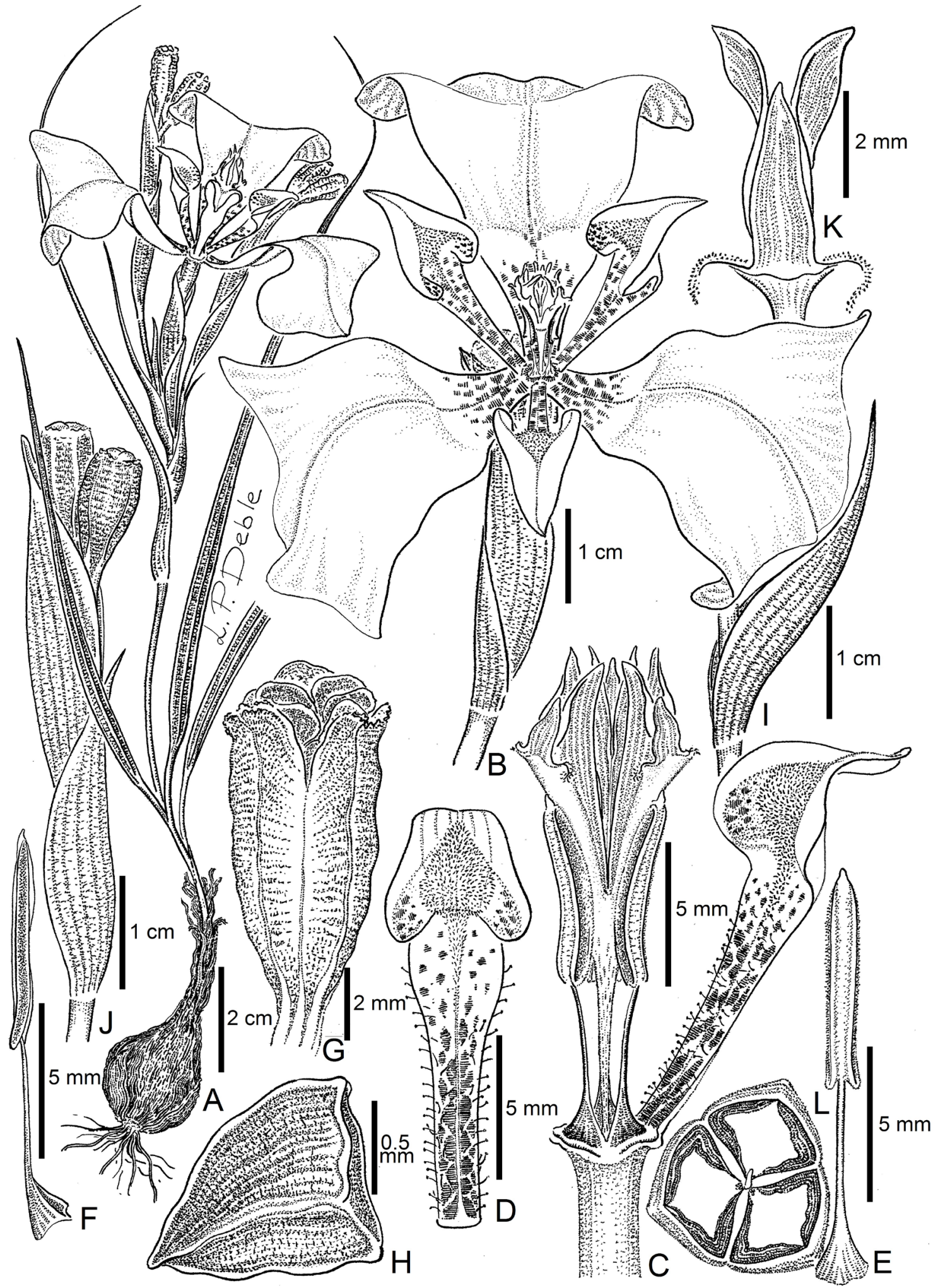

Figure 3. Cypella Hauthalii. A, Habit. B, Flower. C, Flower, with perigone removed, except one inner tepal. D, Inner tepal, upper view. E. Stamen, dorsal view. F, Stamen, lateral view. G, Capsule. H. Seed. I, Bract. J, Spathe, wih two immature fruits. $\mathrm{K}$, Distal portion of style branches, showig crests and stigmtic region. L, Cross-section of capsule. 
Cypella guttata Deble \& F.S. Alves, Phytotaxa 236: 105. 2015. (sect. Cypella). Typus: URUGUAY. Artigas: Sarandy de Arapey, "cerca de 11 $\mathrm{km}$ nordeste da vila de Sarandy de Arapey, $30^{\circ}$ 57' 45.22"'S and 56 06'09.75"O, 22.X.2014, L.P. Deble, A.S. de Oliveira \& F.S. Alves 14991 (holotypus MVFA!, isotypi SI!, ICN!). Figure 1J.

Geographic distribution and habitat - Southwest RS State, Brazil, and Artigas and Rivera departments, northern Uruguay, alongside the oriental portion of the Basin of Quaraí River. Specimens occur on small rivers among rocks and in flooded river banks.

Comments - C. guttata belongs to the same group of $C$. Herbertii, and is closely related to C. Herbertii subsp. brevicristata and C. parviflora. However, can be distinguished from both mentioned taxa by its flowers with central depression painted with red spots, and shape and size of stamens.

Cypella Hauthalii (Kuntze) R. C. Foster, Contr. Gray Herb. Harv. 171: 23. 1950. Bas.: Alophia Hauthalii Kuntze, Rev. Gen. Pl. 3, p. 304. 1898. $\equiv$ Herbertia Hauthalii (Kuntze) Schumann, J. bot. jahr. Syst.26 (1), p. 331. 1900. 三 Trifurcia Hauthalii (Kuntze) Goldblatt, Brittonia 27, p. 384. 1975. Typus: PARAGUAY. Paraguarí: Ybitimí, October 1892, R. Hauthal s.n. [= n. 9] (holotypus NY not seen, isotypi SI [SI0300!], CTES!). Figures 1Y, 3.

Distribution and Habitat- Cypella Hauthalli is narrowly endemic in an area around the hydroelectric complex of Yacaretá, in southwest MI and northern CR Provinces, Argentina, and southern Paraguay, Itapuá and Paraguarí Departments. Specimens occur on grasslands of lateritic and deep soils.

Comments - Cypella Hauthalii is morphologically separated to $C$. opalina (the new combination and status is here proposed) by its bigger and wider spathes, and larger flowers, pallid lilac-blue colored, size and shape of inner tepals, and bigger size of all floral organs. During field activities, no intermediate forms between both species are found.

\section{Cypella Herbertii}

Based on the well-defined morphological groups, C. Herbertii is here segregated into four infraspecific entities as proposed by Ravenna (1964, 1981b), and are listed below.

Cypella Herbertii (Herbert) Herbert subsp. Herbertii,
Bot. Mag. 53:pl. 2637. 1826. Bas.: Tigridia Herbertii Herbert, Bot. Mag. 52: pl. 2599. 1825. $\equiv$ Moraea Herbertii (Herbert) Lindley, Bot. Reg. 11: pl. 949. 1825 [1826]. $\equiv$ Phalocallis Herbertii (Herbert) Kuntze, Rev. Gen. P1. 2: 702. 1891. Lectotypus (here designated): Original plate 2599, Botanical Magazine 25. 1825. Epitypus (designated by Eggers et al. 2019: 759): ARGENTINA. Buenos Aires, s.d., J. Tweedie 765, second plant from right to left (Epitypus K [K000523855 image seen!]). Figure 4.

= Cypella bonariensis (Tenore) Niederl., Bol. Mens. Mus. Prod. Argent. 3 (31): 332. 1890. $\equiv$ Polia bonariensis Tenore, Cat. Orto Bot. Napoli, p. 92. 1845. Typus: ARGENTINA. Buenos Aires, "cultivata nel Real Orto Botanico di Napoli" $F$. Strangvays s.n. (not localized).

= Polia brasiliensis Tenore, Cat. Orto Bot. Napoli: 57. 1845. [nom. nud.]

= Cypella ramosa (Klatt) Klatt, Abhandl. Naturf. Gellesch. Un. Halle. 12: 365. 1882. झ Polia ramosa Klatt, Linnaea 31: 544. 1862. ECypella ramosa Beauverd, Bull. Soc. Bot. Genève ser. 2 (14): 167. 1923 [nom. superfl.]. Typus: BRAZIL/URUGUAY. "Uruguay und Rio Grande do Sul auf der Reise von Montevideo nach Porto Alegre, leg. Sellow no. 765" 1822-1823, F. Sellow 765 (K [K000523858] image seen!).

= Phalocallis Herbertii var. normais Kuntze, Rev. Gen. P. 3 (3): 309. 1898. Typus: ARGENTINA. Buenos Aires, Tandil, without additional data.

= Phalocallis Herbertii var. angustifolia Kuntze, Rev. Gen. P. 3 (3): 309. 1898. Typus: ARGENTINA. Buenos Aires, Tandil, without additional data.

$=$ Phalocallis Herbertii var. latifolia Kuntze, Rev. Gen. P. 3 (3): 309. 1898. Typus: ARGENTINA. Buenos Aires, Tandil, without additional data.

Geographic distribution and habitat - Eastern and Northeastern Argentina (BA, ER, CR, SF, $\mathrm{MI}$ ), all Uruguayan territory and Southern Brazil (RS, SC, PR). Cypella Herbertii subsp. Herbertii occurs preferentially on wet grasslands and bogs, but also can spreads on grasslands and places with anthropic action, as square and gardens. The flowers are auto-pollinized and produce a great number of fruits and seeds.

Comments- C. Herbertii subsp. Herbertii is variable in size and vegetative aspect, but can be recognized by its golden-yellow or orange flowers, stamens with filaments compounding a conical column, anthers longer than the filaments and style-branches whitish towards the base and dark-purple at top, ending in long and darker crests.

Observation - Recently, Eggers et al. (2019) proposed the lectotypification of Cypella Herbertii. However, they used the plate proposed by Lindley instead of Herbert's original board. Over time in 
Deble, L.P. \& F.S. Alves, Cypella: What do we know?

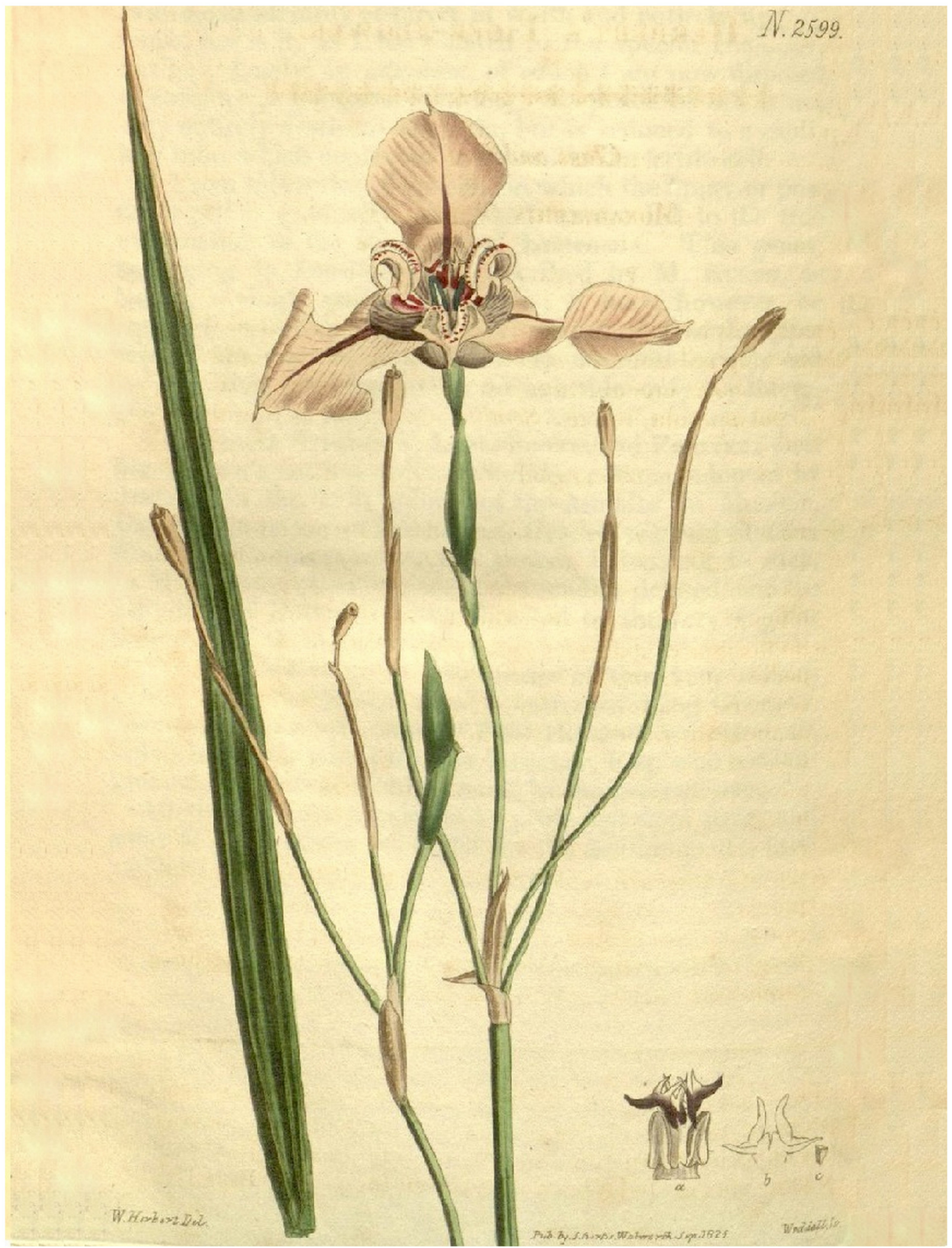

Figure 4. Cypella Herbertii. Lectotype of Tigridia Herbertii, original plate published in Botanical Magazine, ${ }^{\circ}$ 25, plate 2599. 1825. 
several works the publication of Moraea Herbertii Lindley (1825 [1826]: pl. 949) was wrongly attributed to the basyonim of $C$. Herbertii instead of Tigridia Herbertii (Herbert 1825: pl. 2599). In this work we propose the lectotypification based on the figure of the first description of the species (Herbert 1825: pl. 2599).

Cypella Herbertii subsp. brevicristata Ravenna, Not. Bol. Soc. Argent. Botánica 10 (4): 312. 1965. Typus: URUGUAY. Artigas: Artigas, "Culta in Bonaria ex bulbis collectis in septentrione Uruguay in proximus locibus urbi Artigas, in campis inter fruticis" P.F. Ravenna 01, XI.1959 (Herb. Rav. not localized). Neotypus (designated by Deble \& Alves 2017a: 21): URUGUAY. Artigas: Artigas, arroyo Pintadito, 30 25'58.91'S and 56²6'45.02"W, 6.XII.2015, L. P. Deble \& F. S. Alves 15996 (neotypus SI!, isoneotypus: MVFA!). Distribution and Habitat - Northwest Uruguay and Southwest RS, Brazil and probably in Northeast ER and Southeast CR Provinces, Argentina. C. Herbertii subsp. brevicristata is mainly reported to Basin of Quaraí River, occurring since the medium course of the Quaraí River extending its distribution up to mouth with the Uruguay River. Comments - Cypella Herbertii subsp. brevicristata can be distinguished to $C$. Herbertti subsp. Herbertii by its yellow perigone (vs. golden-yellow or orange), with 34-40 mm diameter (vs. 45-55 $\mathrm{mm}$ ), obovate outer tepals (vs. obovate-oblong), stamens with shorter anthers and style branches often with short crests (additional comments see Deble \& Alves 2017a). In analyzing the work of Eggers et al. (2019) it was possible to verify that part of the examined material and reproduced photos (Fig. 11a-b) correspond to subsp. reflexa instead subsp. brevicristata.

Cypella Herbertii (Herbert) Herbert subsp. reflexa Ravenna, Wrightia 7: 22. 1981. Typus: ARGENTINA. Entre Rios: Paraná, "prope Paraná, ad viam Maria Grande prov. Entre Rios Argentinae" XII.1969, P. F. Ravenna 1042 (Herb. Rav. not localized). Figure $1 \mathrm{~K}$.

Distribution and Habitat - Northwest Uruguay (Artigas, Salto and Paysandú Departments), and northeast Argentina (ER, CR). Specimens grow on wet grasslands and grasslands.

Comments - Cypella herbertii subsp. reflexa is closely related to $C$. herbertti subsp. herbertii but can be distinguished by its slender habit, narrowly linear leaves and yellow perigone (vs. golden-yellow or orange), and style branches often with shorter and yellow crests.

Cypella Herbertii subsp. Wolffhuegelii (Hauman) Ravenna, Not. Bol. Soc. Argent. Bot. 10: 312. 1965. Bas.: Cypella Wolffhuegelii HaumanMerck, Apuntes Hist. Nat. 1: 89. 1909. Typus: ARGENTINA. Buenos Aires: Sierra de La Ventana, no date, Hauman-Merck s.n. (Holotypus B, image seen!, isotypus SI [SI014011!]).

Distribution and Habitat - Endemic in Southern BA province, Argentina. The individuals occur on swamp areas and wet grasslands along of the range of the mountains of Ventana and Balcare.

Comments - This subspecies can be recognized by its robust habit (some specimens can reach up to $170 \mathrm{~cm}$ tall), fruits with $25-35 \mathrm{~mm}$ long, and bigger bulbs. The flowers are very similar to $C$. Herbertii subsp. Herbertii; however, the style branches are free end reclined, and the filaments are free.

Cypella laeta Ravenna,Wrightia 7 (1): 13. 1981 (sect. Nais). Typus: ARGENTINA. Entre Ríos: Concordia, "Culta in Bonaria ex bulbis ad Parque San Martín [Parque Rivadávia] pr. Concordiam prov. Entre-Rios Argentinae collectis", XII.1967, P. F. Ravenna 506 (Herb. Rav., not localized). Lectotypus (here designated) ARGENTINA. Entre Rios: Concordia, Estación Agronomica, 16.I.1927, A. Burkart 784 (lectotypus SI!). Figure $1 \mathrm{~L}$.

= Cypella yatayphila Ravenna, Onira Botanical leaflets 12 (1): 3. 2009. Typus: ARGENTINA. Entre Ríos: Colón, Parque Nacional El Palmar, 31 $52^{\prime} 29^{\prime}$ 'S 58 $12^{\prime} 36^{\prime}$ "W, "patio de la Intendencia" 15-16.XI.2003, A. A. Cocucci et al. 2926 [=2916]" (holotypus SI!, isotypus CTES!).

Geographic distribution and habitat- Cypella laeta is micro-endemic in sedimentary areas in eastern ER Province, Argentina, and western Uruguay (Salto and Paysandú Departments).

Comments - C. laeta is easily identified by its two flowered spathes, borne on long peduncles, and yellow-ochraceous flowers. C. laeta can be confused with $C$. suffusa Ravenna, an endemic species of the MI Province, Argentina, which grows distant more than $500 \mathrm{~km}$ of the populations of C. laeta. Further on the geographic isolation, both species can be distinguished by the morphologic attributes mentioned in the dichotomous key. Observation - The neotype designated by Deble \& Alves (2017: 52) must be rejected, considering 
that during the study of the material separated for Flora de Entre Ríos (Deble, unp. data) was localized among the indeterminated Iridaceae three original paratypes of $C$. laeta, being the collection Burkart 784 designated as lectotype.

Cypella lapidosa Ravenna, Wrightia 7 (1): 21. 1981 (sect. Cypella). Typus. ARGENTINA. Corrientes: "Dep. Santo Tomé, Garruchos, Estancia San Juan Bauptista, costa del rio Uruguay, en pedregal, 20-II-1974", A. Krapovickas et al. 25815 (holotypus: Herb. Rav., not localized). Lectotypus (here designated): ARGENTINA. Corrientes: "Dep. Santo Tomé, Garruchos, Estancia San Juan Bauptista, costa del rio Uruguay, en pedregal, 20II-1974" 20.IX.1974 (fl.), A. Krapovickas et al. 25815 (lectotypus CTES [CTES0000230!]). Figure $1 \mathrm{M}$.

= Cypella altouruguaya Chauveau \& L. Eggers, Phytotaxa 174 (1), p. 26. 2014. Typus: BRAZIL. Rio Grande do Sul: Trindade do Sul, "Estrada Trindade do Sul - Pinhalzinho, 610 m" 3.XII.2011 (fl, fr), T.B. Guimarães \& L. Dal Ri 6 A (holotypus ICN [ICN173593!]).

Geographic distribution and habitat- Eastern and northeast CR and southern MI Province, Argentina, and northwestern RS State, Brazil. Specimens grow since shallow soils, among rocks and stony, up to lateritic and deep soils, associated with shrubs and small trees.

Comments-C. lapidosa is closely related to $C$. exilis, and can be distinguished by its perigone shiny yellow or golden-yellow (vs. orange), without stains in the blade of the outer tepals, by its short and thickened filaments, and by its style branches with short and fimbriate abaxial crest.

Observation - Eggers et al. (2019) considered $C$. altouruguaya as segregated, due original material of C. lapidosa is from CR Province (Argentina) vs. RS State, Brazil, and also due morphological features of C. altouruguaya, as bigger size of floral organs, different shape of staminal filaments, and spathes with longer outer valve. However, we examined several populations of this plant in the nature in CR and MI Provinces, Argentina, and Northwestern RS State and no doubt that both are the same species, and the variation of size of floral organs and color of flowers (light-yellow to golden-yellow) is observed in individuals of the same population.

Cypella laxa Ravenna, Wrightia 7 (1): 15. 1981 (sect. Nais). Typus: BRAZIL. Paraná: Guarapua- va: "In uliginosis, circ. $2 \mathrm{~km}$ a Posto Agropecuario mun. Guarapuavae civit. Paranaensis Brasiliae", 3.XII.1969, P. F. Ravenna \& G. Hatschbach 1008 (holotypus Herb. Rav. not localized). Lectotypus (designated by Eggers et al. 2019: 752): BRAZIL. Paraná: Guarapuava: "In uliginosis, circ. $2 \mathrm{~km}$ a Posto Agropecuario mun. Guarapuavae civit. Paranaensis Brasiliae", 3.XII.1969, P. F. Ravenna \& G. Hatschbach 1008 (lectotypus K [K000322475] image seen!). Figure 1N.

Geographic distribution and habitat - A common species in Brazil (RS, SC, PR, MS, southern SP), northeast Argentina (CR, MI) and southern and eastern Paraguay. The specimens occur exclusively on bogs.

Comments - C. laxa is easily identified by its small bulbs, having straw-colored cataphylls, narrowly linear leaves, and spathes long pedunculate and one flowered. Furthermore, the fruits are bigger, with thin pericarp, and containing a great number of seeds.

Obsevation - Eggers et al. (2019) merged this species under $C$. crenata; however, we prefer to keep it as segregated, based on the distinctive characters listed by Ravenna (1981b) and the analyzes of the original materials of C. paludosa, which is also the same epitype proposed by Eggers et al. (2019: 752), which evidence longer staminal filaments and narrower inner tepals.

Cypella luteogibbosa Deble, Phytotaxa 71 (1): 60. 2012 (sect. Cypella). Typus: BRAZIL. Rio Grande do Sul: Quaraí, "28 km ao sul do trevo para o Passo da Guarda", 19.X.2010, fl., fr., L. P. Deble \& A. S. de Oliveira-Deble 10265 (holotypus PACA!). Figure 10.

Geographic distribution and habitat - Endemic in southwest RS State, Brazil, and Artigas Department, Northern Uruguay. Specimens occur on hillsides stony, and native grasslands, often stony. Comments - C. luteogibbosa is similar to C. fucata and $C$. Osteniana, and can be distinguished to the former by its white flowers and shape of inner tepals. From $C$. Osteniana, the species differs mainly by its one flowered spathes and different shape of inner tepals.

Cypella magnicristata Deble, Phytotaxa 71 (1): 63. 2012 (sect. Cypella). Typus: BRAZIL. Rio Grande do Sul: Quaraí, Jarau, 30¹1'34.07'S, 56²9"58.86"W, 17.II.2011, fl., fr., L. P. Deble \& A. S. de Oliveira-Deble 12816 (Holotype: PACA!). 
Figure 1P.

Geographic distribution and habitat- Endemic in southwest RS State, Brazil. Recently, populations of $C$. magnicristata were registered in hills of the "Serra do Caverá", increasing the geographic distribution of this species (Deble et al., unp. data). Specimens occur exclusively on hillsides often stony, associated with shrubs.

Comments - C. magnicristata is similar to C. armosa and $C$. trimontina, and can be distinguished from these species by its bigger size of the flowers (are the biggest of the genus Cypella until this moment), with central concavity painted with red spots, and inner tepals broader.

\section{Cypella opalina}

A new combination and status are subsequently proposed to $C$. Hauthalii subsp. opalina and a new combination to $C$. Hauthalii subsp. minuticristata. These taxonomic novelties are based in morphologic attributes and also on multivariate analysis by the method of the Euclidean distance in populations of $C$. Hauthalii, which evidenced the subspecies opalina and minuticristata as closely related and segregated of $C$. Hauthalii (Deble et al., unp. data).

Cypella opalina (Ravenna) Deble, comb. et stat. novo. Bas.: C. Hauthalii subsp. opalina Ravenna, Wrightia 7 (1): 21. 1981. Typus: ARGENTINA. Corrientes: Santo Tomé, Garruchos: "Culta in Santiago ex bulbo ad ripas fluminis Uruguay pr. Garruchos prov. Corrientes Argentinae collecto" X.1980, P.F. Ravenna 3300 (Herb. Rav., not localized). Lectotypus (here designated): ARGENTINA. Corrientes: Santo Tomé, Garruchos: "Estancia San Juan Bautista, costa del río Uruguay, campo bajo inundado" 20.IX.1974, A. Krapovickas et al. 25807 (lectotypus CTES [CTES0000225!]). Figures $1 \mathrm{Z}, 5 \mathrm{~A}-\mathrm{M}$.

Geographic distribution and habitat - Northeast Argentina (Southern MI and northeast CR Provinces), western, northwestern and central RS, Brazil, and recently found also in southern Paraguay, Itapuá Department (De Baltezan et al. 2019). The populations are composed by many individuals who grow on native grasslands, preferentially on place of shallow soils, stony and rocks but also on deep lateritic soils developed from volcanic rocks of Serra Geral geological formation. This species is most frequent between Garruchos (Argentina) and Santiago, RS State (Brazil), where occurs in a stripe more or less continuous with ca. of $60 \mathrm{~km}$ wide, along the Basin of Icamacuã and Piratini River in RS State, and in north of the Arroyo Cuay Grande in CR Province. Along this area, is the most common species of bulbous Iridaceae, but become rare outside this region.

Comments - Cypella opalina is segregated of $C$. Hauthalii mainly based in the following morphologic attributes: white flowers (vs. pallid lilac-blue), outer tepals almost erect in proximal half (vs. outer tepals ascendant in proximal half); inner tepals shorter than the central concavity ( $v s$. inner tepals longer than the central concavity), central concavity many deep and narrower (vs. central concavity few deep and wider), and smaller style (13-17 mm vs. 18-23 mm). Additional attributes to distinguish both species are listed in the Table 2 .

Cypella opalina subsp. minuticristata (Chauveau \& L. Eggers) Deble, comb. nova. Bas.: Cypella hauthalii subsp. minuticristata Chauveau \& L. Eggers, Phytotaxa 174 (1): 33. 2014. Typus: BRAZIL. Rio Grande do Sul State: Soledade, "Comunidade Margem São Bento, propriedade particular do Sr. Waldemar Freitag, 534m", $28^{\circ} 48^{\prime}$ 52.8"S and $52^{\circ} 38^{\prime} 38.9^{\prime}$ 'W, 2.XI.2013, L. Eggers et al. 833 (holotypus ICN!). Figures 5N-O.

Geographic distribution and Habitat - Endemic in central region of RS State, Brazil. The populations are composed by many individuals who grow on native grasslands, preferentially on deep and clay soils. In the municipality of Soledade specimens was found grow sympatric with the typical subspecies.

Comments - Cypella opalina subsp. minuticristata differs to $C$. opalina by its style branches with obsolete or up to $2 \mathrm{~mm}$ long crests at top and narrower inner tepals. In the Table 2 are listed additional morphologic attributes to distinguish C. Hauthalii, C. opalina subsp. opalina and C. opalina subsp. minuticristata.

Cypella Osteniana Beauverd, Bull. Soc. Bot. Genève ser. 2 (14):165. 1923. Typus: URUGUAY. Minas: "loco dicto Verdun, in saxosis, Cypella cf. plumbea Lindley, perigon bräunlichweiss, innere, zurückgebogen gelb, braun marmorirt" 16.IV.1908, C. Osten 5197 (holotypus MVM [MVM 18457!]). Figure 1Q.

Geographic distribution and Habitat - Cypella Osteniana occurs on stony grasslands and hillsides stony in southern and eastern Uruguay. 
Comments - This species is easily identified by its two flowered spathes and smaller and white-ochraceous flowers. Despite its morphologic peculiarities, $C$. Osteniana can be confused to $C$. luteogibbosa, but the later species has one flowers per spathe, different shape of inner tepals, and broader central concavity of the flowers. From C. Alonsoana distinguishs by its smaller size of vegetative parts, measurement of flowers, and different collor of perigone.

Table 2. Characters to distinguish Cypella Hauthalii and C. opalina.

\begin{tabular}{|c|c|c|c|}
\hline Character/taxon & C. Hauthalii & C. opalina subsp. opalina & C. opalina subsp. minuticristata \\
\hline Size of spathes $(\mathrm{cm})$ & $3.4-5.5 \times 0.5-0.8$ & $2.4-4.8 \times 0.4-0.5$ & $2.9-4 \times 0.3-0.4$ \\
\hline Peduncles of spathes length $(\mathrm{cm})$ & $1.4-4.5$ & $0.6-2.8$ & $0.9-2.6$ \\
\hline General aspect of flowers & $\begin{array}{l}\text { outer tepals ascendant in proximal } \\
\text { half; inner tepals longer than the cen- } \\
\text { tral concavity; central concavity few } \\
\text { deep and wider }\end{array}$ & $\begin{array}{l}\text { outer tepals almost erect in distal half; } \\
\text { inner tepals shorter than the central } \\
\text { concavity; central concavity many } \\
\text { deep and narrower }\end{array}$ & idem subsp. opalina \\
\hline Perigone color & $\begin{array}{l}\text { pallid lilac-blue, more darker at the } \\
\text { end of the anthesis }\end{array}$ & $\begin{array}{l}\text { white, subtly tinged of white-cream } \\
\text { at beginning of the anthesis become } \\
\text { bluish at the end of the anthesis }\end{array}$ & $\begin{array}{l}\text { White, subtly tinged of white-blue } \\
\text { at beginning of the anthesis become } \\
\text { more blue at the end of the anthesis }\end{array}$ \\
\hline Perigone diameter $(\mathrm{cm})$ & $4.8-6.5$ & $3.3-5$ & $3.5-5$ \\
\hline Outer tepal shape and length $(\mathrm{mm})$ & oblong-spathulate, $38-45$ & Spathulate or obdeltate, $25-35$ & idem subsp. opalina \\
\hline Inner tepal size & $22-28 \times 7-8.5$ & $15-17 \times 5-6$ & $14-16 \times 4-5$ \\
\hline Anthers length (mm) & $6.5-7.5 \times 1.1-1.4$ & $5-6 \times 1.2-1.6$ & $4.5-6 \times 1.1-1.5$ \\
\hline Pollen color & bluish grey & ochraceous or yellow & idem subsp. opalina \\
\hline Filaments color and length $(\mathrm{mm})$ & $\begin{array}{l}\text { light blue at apices, then purple at the } \\
\text { base, } 7-9\end{array}$ & $\begin{array}{l}\text { white, with parallel stripes in proxi- } \\
\text { mal half and purple at the base, } 5-6.5\end{array}$ & idem subsp. opalina \\
\hline $\begin{array}{l}\text { Style length (including style } \\
\text { branches) }(\mathrm{mm})\end{array}$ & $18-23$ & $14-17$ & $13-15$ \\
\hline $\begin{array}{l}\text { Style branches color and length } \\
(\mathrm{mm})\end{array}$ & light-blue, 6-7 & white or bluish at top,3-4 & bluish at top, $2.5-3.5$ \\
\hline Adaxial crests length (mm) & $4-5.5$ & $2.5-5$ & $0.1-1.5(-2)$ \\
\hline Geographical distribution & $\begin{array}{l}\text { southwest Misiones and North Cor- } \\
\text { rientes Provinces, Argentina, and } \\
\text { southern Paraguay }\end{array}$ & $\begin{array}{l}\text { southern Itapuá Department, southern } \\
\text { Paraguay, southern MI and northeast } \\
\text { CR Provinces, Argentina, and west- } \\
\text { ern, northwestern and Central RS, } \\
\text { Brazil }\end{array}$ & Central RS, Brazil \\
\hline
\end{tabular}

Cypella Pabstiana Ravenna, Wrightia 7 (1): 18. 1981. Typus: BRAZIL. Paraná: Guarapuava, Entre Rios, "in campis siccis graminosis ad Entre Rios mun. Guarapuava civit. Parana Brasiliae" 4.XII.1969, P. F. Ravenna \& G. Hatschbach 1013 (holotypus Herb. Rav., not localized). Lectotypus (designated by Eggers et al. 2019: 767): BRAZIL. Paraná: Guarapuava, Entre Rios, "campo limpo, seco", 21.X.1969, G. Hatschbach 22552 (Lectotypus MBM [MBM 12074!]).

Geographic distribution and Habitat - Cypella Pabstiana was originally described on dry grasslands of Entre Rios, a locality of Guarapuava municipality, central-eastern PR State, but since the two vouchers mentioned in the protologue, this species still waiting to be found again.

Comments- C. Pabstiana was not localized during botanic expeditions performed in November 2013, February 2014, and November/December 2016. The natural grasslands which are the habitat of C. Pabstiana were strongly modified by the agriculture, and the local of occurrence mentioned by Ravenna (1981b: 18) in the protologue was detailedly investigated during the expeditions above mentioned and this species was not found, suggesting that $C$. Pabstiana is extinct.

Cypella parviflora Ravenna ex Deble \& F. S. Alves, Kew Bulletin 72: 47. 2017 (sect. Cypella). Typus: ARGENTINA. Corrientes: Santo Tomé, Garruchos, 3.X.2015, L. P. Deble \& F. S. Alves 15619 (holotypus SI!, isotypi CTES!, ICN!, K). Figure 1R.

Geographic distribution and Habitat - Cypella parviflora occurs in northeastern CR Province, Argentina. Specimens were found in moist soils and deep, of flood plains and banks of the Garabí River, extending up to its mouth with the Uruguay River. The area of occurrence is susceptible to be submerged by floods of Uruguay River and its tributaries. 
Comments - Cypella parviflora is similar to $C$. Herbertii subsp. brevicristata and C. guttata, and can be distinguished of the first taxon by its reduced habit, smaller flowers, shorter and slender filaments, and shorter style, with style branches displaying small transverse stigmatic surface of the abaxial crest. From C. guttata, this species is separated mainly by its shorter and broader leaves, flowers with perigone not painted, outer tepal blades short and slightly patent, and seeds with epidermis shaped like a honeycomb.

Cypella pusilla (Link \& Otto) Benth. \& Hook. f. ex B. D. Jacks., Index Kewensis 1: 689. 1893 (sect. Nais). Bas.: Ferraria pusilla Link \& Otto, Ico. Pl. Select. 10: 125. 1828. $\equiv$ Herbertia pusilla (Link \& Otto) Sweet, Hort. Brit., ed. 2: 497. 1830. 三Polia pusilla (Link \& Otto) Klatt, Linnaea 31: 545.1862. $\equiv$ Hesperoxiphion pusillum (Link \& Otto) Baker, Jour. Linn. Soc., Bot. 16: 127. 1877. $\equiv$ Phalocallis pusilla (Link \& Otto) Kuntze, Rev. Gen. P1. 2: 702. 1891. Epitypus (designated by Deble \& Alves 2017b): BRAZIL. Rio Grande do Sul State: Porto Alegre/Encruzilhada do Sul, "Brésil Province de Rio-Grande (Herbier Impérial du Brésil 294), C. Gaudichaud 1833" F. Sellow 2599 (epitypus P [P01846365 image seen!]). Lectotypus (designated by Pastori et al., 2018): BRAZIL. Rio Grande do Sul: Porto Alegre,"Die zwiebeln sandte Herr Sello aus Brasilien von Porto Alegre in jahre 1826", I.1826, F. Sellow s.n. Icon. P1. Select. 125: pl. 59. Figure $1 \mathrm{~S}$.

Geographic distribution and Habitat - C. pusilla is endemic in RS State, Brazil, where was registered on stony grasslands and mountainous places in central, eastern and southwest of the State.

Comments - This species is the smallest species of the section Nais, specimen reach only up to 20 $\mathrm{cm}$ high, the flowers have less than $40 \mathrm{~mm}$ diameter, and the spathes are sessile or almost sessile, being by attributes mentioned easily distinguished to the others species of the genus. Despite its morphologic peculiarities, $C$. pusilla is related to the recently described $C$. gloriana, which displays bigger flowers, with broader and less deep central concavity, outer tepals with narrowed claws, inner tepals with blades markedly narrower, and longer upwards, and with glandular trichomes spreading in a small area, stamens shorter, with reclined filaments, smaller anthers, and broader connective.
Cypella Ravenniana Deble \& F.S. Alves, Phytotaxa 236 (2): 109. 2015 (sect. Nais). Typus: ARGENTINA. Corrientes: Santo Tomé, Garruchos, "Estancia San Juan Bauptista, on stony rocky grassland, $28^{\circ} 10^{\prime} 20,54$ ' $\mathrm{S}-55^{\circ} 38^{\prime} 14,33$ ' $\mathrm{W}$, 22.XII.2014, L. P. Deble \& F. S. Alves 15505 (holotypus SI!, isotypi CTES!, ICN, MVFA!). Figure $1 \mathrm{~T}$.

Geographic distribution and Habitat - Cypella Ravenniana occurs in northeast Argentina (southern MI Province, and northeast CR), and western and northwestern RS State, Brazil. The populations are fragmented, but composed often by many individuals, who grow on native grasslands, in places of shallow soils, stony and rocky. The bulbs usually grow in rock crevices (additional notes see Deble et al. 2015a).

Comments - Cypella Ravenniana is one of the most attractive species of the genus, by the contrast of its smaller habit and bigger and shiny yellow flowers painted by reddish-brown stains. The specimens flowering abundantly during several months of the year. This species resembles $C$. suffusa, but can be separated by its short pedunculate spathes, containing only one flower, by shape of the central concavity of perigone, larger and less deep, by absence of conspicuous purple stains in the middle portion of the outer blade of the tepal, and by stamens with filaments not adhered to style in the proximal half.

Cypella rivularis Chauveau \& L. Eggers, Phytotaxa 174 (1): 36. 2014. (sect. Nais). Typus: BRAZIL. Rio Grande do Sul: Uruguaiana, BR 290, "aproximadamente $\mathrm{Km}$ 645, campo bem preservado, em baixada, em borda de pequenos riachos, 172 m", fl. and fr. 25.XI.2013, L. Eggers et al. 869 (holotypus: ICN!). Figure 1U.

Geographic distribution and Habitat- Cypella rivularis occurs in southwest RS State, Brazil and northwest Artigas Department, Uruguay. The populations grow on wet grasslands near to small rivers of fast flowing water.

Comments - Cypella rivularis is one of the most beautiful species of the genus, the flowers are bigger and shiny yellow, with tepals firm in texture, painted with reddish-brown spots. This species is easy identified by shape of inner tepals and bigger size of floral organs. Based in the attributes mentioned above, the relationships with others species of the genus are uncertain. 


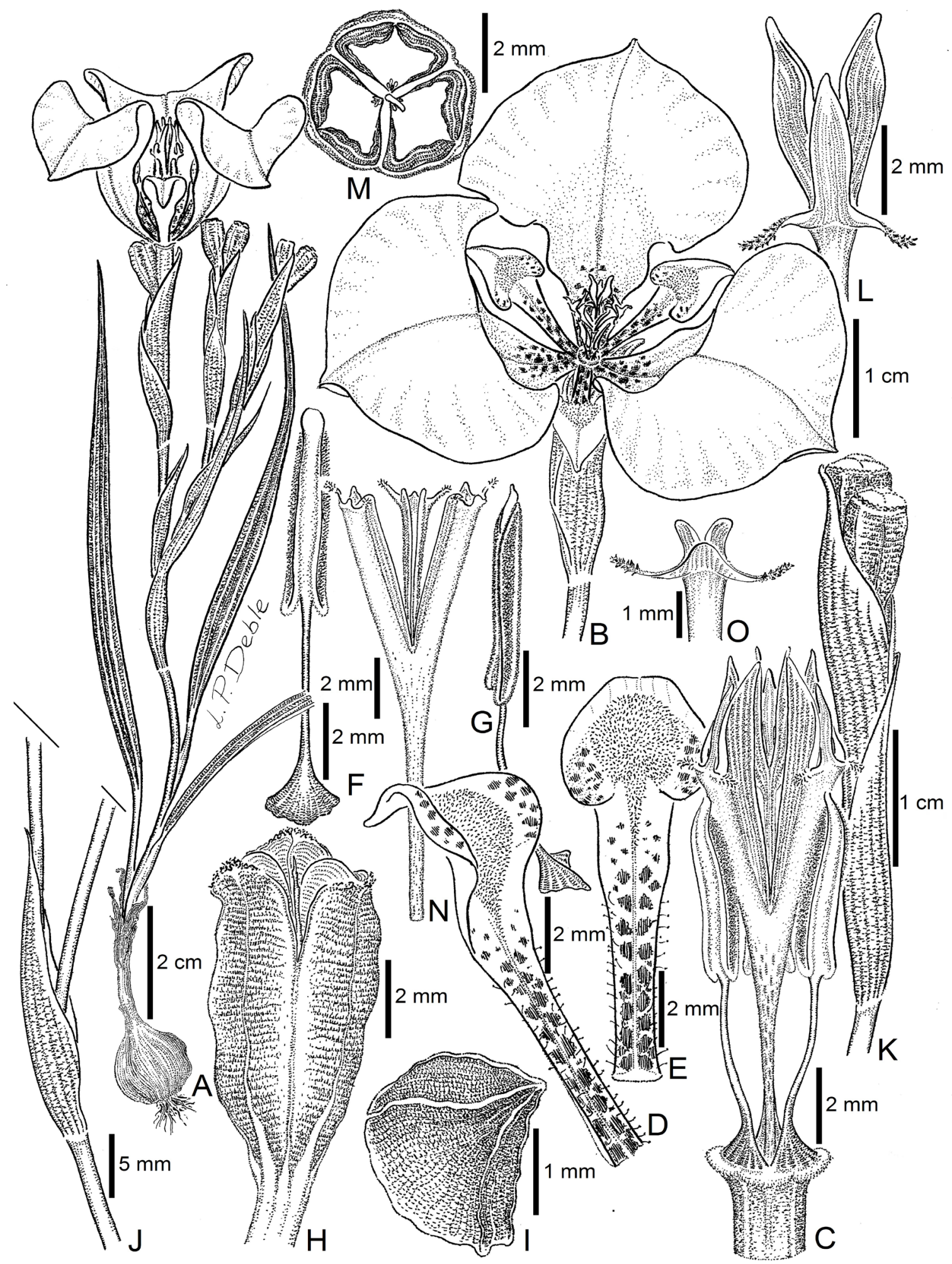

Figure 5. Cypella opalina. A, Habit. B, Flower. C, Flower, with perigone removed. D, Inner tepal, lateral view. E, Inner tepal, upper view. F. Stamen, dorsal view. G, Stamen, lateral view. H, Capsule. I, Seed. J, Bract. K, Spathe, wih two immature fruits. L, Distal portion of style branches, showig crests and stigmtic region. M, Cross-section of capsule. Cypella opalina subsp. minuticristata. N, Style. O. Distal portion of style branches, showig crests and stigmtic region. 
Cypella suffusa Ravenna Onira Botanical leaflets 12 (1): 1. 2009 (sect. Nais). Typus: ARGENTINA. Misiones: Cainguás, "predio UNLP, reserva privada, valle del arroyo Cuña Pirú, campito 1", $27^{\circ} 06$ ' 44" S, 54 58' 23" W, 15.III.2000, Peralta et al. [= F. Biganzoli 830 et al.] (holotypus SI!, isotypus CTES!). Figure $1 \mathrm{~V}$.

Geographic distribution and Habitat - Narrowly endemic in northeast Argentina (central region of MI Province). Cypella suffusa is one of the rarest species of the genus, occurring on small areas of native grasslands among the forest. Individuals grow on stony grasslands with shallow soils often associated with Dyckia spp. (additional comments see Deble et al. 2015a).

Comments - Cypella suffusa is closely related to $C$. laeta, since both species have longer pedunculate spathes, containg two flowers. However, $C$. suffusa can be distinguished by its golden-yellow flowers, bigger size of perigone, shape of inner tepals and stamens with filaments more thickened and yellow.

Cypella trimontina Ravenna, Onira Botanical leaflets 12 (1): 2. 2009. (sect. Cypella). Typus: ARGENTINA. Corrientes: San Martín, La Cruz, Tres Cerros, 22.X.1976, A. L. Cabrera 28162 (holotypus SI!, isotypus CTES!). Figure 1W.

Geographic distribution and Habitat - Northeast Argentina (central-eastern region of CR Province). Cypella trimontina is micro-endemic in the locality of Paraje Tres Cerros, La Cruz municipality, San Martín Department. The individuals occur in hillsides, on stony grasslands associated to rocks, made of quartz sandstone.

Comments - Cypella trimontina is related to $C$. armosa Ravenna, which also occurs in the same Argentinian Province. However, C. trimontina spreading in different habitat, because grows exclusively in slope of hills, on stony grasslands; furthermore, C. trimontina displays inner tepals with broadly cuneate claws, and longer staminal filaments. C. magnicristata, an endemic species of southwest RS, Brazil, perhaps is the most similar to $C$. trimontina; however, $C$. trimontina can be distinguished for this species by its rigid leaves, and small size of flowers and narrower inner tepals.

Cypella uliginosa Deble \& F. S. Alves, Darwiniana, nueva serie, 3(2): 237. 2015 (sect. Nais). Typus: ARGENTINA. Corrientes: San Martín, La
Cruz, Provincial Route 114, close to the "Bañado Guaviravi", in boggy land, flowers pale-yellow, $29^{\circ} 10^{\prime} 07,15^{\prime}$ ' S, $56^{\circ} 42^{\prime}$ 51,30" W, 22-XII-2014 (fl., fr.), L. P. Deble \& F. S. Alves 15181 (holotypus SI!, isotypus MVFA!). Figure 1X.

Geographic distribution and habitat - Northeastern Argentina (Provinces of ER and CR), and Southern Paraguay (Deble \& Alves, unp. data). The individuals grow exclusively in boggy soils. Comments - Cypella uliginosa is similar to $C$. laxa, since both have similar aspect and habitat; however, C. uliginosa displays more robust habit, bigger bulbs, and different flowers with tepals having claws pallid translucent, with central concavity few deep, blade of inner tepals deeply folded, with a deep central depression, marked by a darker area covered by ochraceous glandular trichomes, and erect or slightly porrect style branches, with stigmatic trichomes prolonged on the proximal portion of the adaxial crests.

\section{Excluded species}

Cypella boliviana Huaylla, Kew Bull. 67: 297. 2012. Typus: BOLIVIA. Santa Cruz: Germán Busch, 70 a 80 km del Carmen Rivero Torrez, sobre el camino hacia el Rincón del Tigre. Zona de serranías bajas y ondulantes con suelos arenosos $\mathrm{y}$ con afloramientos rocosos cubiertos por vegetación tipo Cerrado, estacionalmente quemado y con algunos lugares más abiertos y zonas húmedas en los vallecitos $\left[18.1648^{\circ} \mathrm{S} 58.1504^{\circ} \mathrm{W}\right]$, Wood \& Villarroel 25468 (holotypus USZ not seen, isotypi $\mathrm{K}$ not seen, LPB [LPB0000311 image seen!]). = Phalocallis geniculata (Klatt) Ravenna.

Comments - This species was described as restrict to the cerrados of eastern Bolivia. The analyses of the type and the photos reproduced in the protologue (Huaylla \& Wood 2012) evidences $C$. boliviana as cospecific with Phalocallis genicula$\mathrm{ta}$, one species described to the dry grasslands of the region of Camapuã, MS, western Brazil, and also with vouchers in Campo Grande and neighboring areas, distant ca. of only $200 \mathrm{~km}$ of the type of C. boliviana.

Cypella brasiliensis (Baker) Roitman \& A. Castillo, Darwiniana 45 (2): 238. 2007. 三 Kelissa brasiliensis (Baker) Ravenna, Adansonia 1 (1): 106. 1981. $\equiv$ Herbertia brasiliensis Baker, Journ. Linnean Society, London 16 (89): 134. 1877. $\equiv$ Alophia brasiliensis (Baker) Kuntze, Rev. Gen. Pl. 3 (2): 304. 1898. 三 Trifurcia brasiliensis (Baker) 
Goldblatt, Brittonia 27 (4): 384. 1975. 三 Herbertia drummondiana Klatt (non Herbert), Linnaea 31: 555. 1862. Lectotypus (designated by Ravenna 1981: 106): BRAZIL. Rio Grande do Sul: Porto Alegre/Encruzilhada do Sul: "Brasilia meridionalis, IX/X.1825, F. Sellow 2863I" (lectotypus B image seen!, isolectotypus $G$ image seen!). Syntypus: BRAZIL. Rio Grande do Sul State: Porto Alegre/Encruzilhada do Sul: "Brasilia meridionalis, IX/X.1825, F. Sellow 1370 (B image seen!). Figure 1A'.

= Sympa riograndensis Ravenna, Wrightia 7 (1): 11. 1981. Typus: BRAZIL. Rio Grande do Sul: São Gabriel "17 km. W de Sao Gabriel, campo com baixada umida" 13.X.1971, J. C. Lindman et al. [p.p.] (holotypus ICN [ICN08345!]).

Comments - Cypella brasiliensis was a name proposed by Roitman \& Castillo (2007); however, the style columnar, filiform, and without crests at top, being hidden by the stamens, and the stamens with connected filaments, forming a column which enclosing the style is very distinct and not agree with found in Cypella. As consequence, Kelissa must be maintained as a segregated genus as firstly proposed by Ravenna (1981c).

Cypella geniculata (Klatt) Ravenna, Revista Inst. Munic. Bot. (Buenos Aires) 2: 53. 1964. $\equiv$ Phalocallis geniculata (Klatt) Ravenna, Not. Mens. Mus. Nac. Hist. Nat. 21: 9. 1977. $\equiv$ Alophia geniculata Klatt, Fl. Bras. 3 (1): 517.1871 . $\equiv$ Sphenostigma geniculatum (Klatt) Klatt, Abh. Naturf. Ges. Halle 15: 363. 1882. Typus: BRAZIL. Mato Grosso do Sul: Camapuã, "in campis siccis collibusque prope Camapuan prov. Mato Grosso", A.F. Regnell s.n. (holotypus $\mathrm{S}$ not seen, isotypus $\mathrm{P}$ [P02065191 image seen!]). Figure 1C'.

Comments - The morphologic attributes of Cypella geniculata, such as bulbs with glutinous and orange cataphylls, flowers with long glandular trichomes on the margin of the blade of the inner tepals, and petaloid style branches evidences this species as belonging at the genus Phalocallis as suggested by Ravenna (1977a) and Ravenna (2003a).

Cypella oreophila Spegazzini, Physis 3: 44.1917 $\equiv$ Phalocallis oreophila (Spegazzini) Ravenna: Not. Mens. Mus. Nac. Hist. Nat. 21: 9. 1977. Typus: ARGENTINA. Jujuy: "en la cuesta de San Antonio, entre Trancas y Pampa Grande", 2,000m a.s.1., 13.I.1897, C. Spegazzini (Holotypus LP [LP003216!]). Figure 1D'.

Comments - The morphologic attributes of Cypella oreophila, including bulbs with glutinous and orange cataphylls, flowers with long glandular trichomes on the margin of the blade of the inner tepals, and petaloid style branches evidences this species as belonging at the genus Phalocallis as firstly suggested by Ravenna (1977b) and Ravenna (2003a).

Cypella unguiculata (Baker) Roitman \& A. Castillo, Darwiniana 45 (2), p. 238. 2007. 三 Onira unguiculata (Baker) Ravenna, Nordic. J. Bot. 3: 204. 1983. E Herbertia unguiculata Baker, Handb. Irid.: 72. 1892. 三 Alophia unguiculata (Baker) Kuntze, Rev. Gen. Pl. 3 (2): 304. 1898. 三 Trifurcia unguiculata (Baker) Goldblatt, Brittonia 27 (4): 384. 1975. Typus: BRAZIL. Rio Grande do Sul: "Hab. South Brazil, Sello!" F. Sellow s.n. (holotypus B not seen, isotypi G image seen! K, not seen). Figure 1B'.

Comments - Cypella unguiculata was a name proposed by Roitman \& Castillo (2007); however, the style filiform, trifid at top, ending in a stigmatic portion and without crests, and the stamens with connective linear is very distinct and not agree with found in Cypella. As consequence, we prefer to maintain Onira as segregated of Cypella as proposed by Ravenna (1983, 2009).

\section{Doubtful taxa}

Cypella craterantha Ravenna, Revista del Instituto Municipal de Botánica 2: 52. 1964. Typus: PERU. Cajamarca: "Culta in Bonaria ex bulbis collectis in Peruviae, in convalle flumins Chicama ad praedium Sunchobamba (Casa Grande), Cajamarca, circ. 2900 m, Dec-Jan 1961-1962" (holotypus Herb. Rav., not localized).

Comments - This species so far is a mystery, and in the list of Iridaceae endemic of Peru is mentioned only the type-locality (León 2006). Ravenna (1981a) mentioned $C$. craterantha as belonging at one undescribed genus. Based in the original description and collection perfomed in the typical locality (Cubas \& Deble, unp. data.), was evidenced this species as not belong to the genus Cypella (see Ravenna 1964).

Cypella elegans Spegazzini, Physis 3: 43. 1917. Typus: ARGENTINA. Salta: "En el talude del ferrocarril entre Fraile Pintao y Ledesma, Salta, en plena floración" I.1897, C. Spegazzini s.n. (not localized).

Comments - According to the original descrip- 
tion, C. elegans resembles Larentia linearis (Spegazzini 1917); however, by the absence of type, and the need of botanical researchs in the locality indicated in the protologue we maintained C. elegans as an uncertain taxonomic entity.

Cypella Herbertii (Herbert) Herbert subsp. reflexa Ravenna f. palmeti Ravenna, Wrightia 7 (1): 22. 1981. Typus: ARGENTINA. Entre Ríos: Ubajay, "In herbosis inter palmas Butiae-yatay ad "Palmar de Colon" prov. Entre Rios, Argentinae”,XII.1969, P.F. Ravenna 1043 (holotypus Herb. Rav., not localized).

Comments - Ravenna (1981b: 22) described the form palmeti to $C$. Herbertii subsp. reflexa based in the orange perigone and blade of outer tepals not spotted. More recently, the same author proposed Cypella yatayphila and reduced C. Herbertii subsp. reflexa f. palmeti to synonym of this species (Ravenna 2009). The comparison of the holotype of $C$. yatayphila and topotypical populations demonstrated this species as a synonym of $C$. laeta, one species of the sect. Nais; however, the description of $C$. Herbertii subsp. reflexa f. palmeti evidences this taxon as distinct of $C$. laeta and belonging to sect. Cypella. During botanical expeditions in Ubajay were found two species of Cypella sect. Cypella: C. armosa Ravenna and C. fucata Ravenna, and the first one probably corresponds to C. Herbertii subsp. reflexa f. palmeti. The area of the Palmar de Colon corresponds to the southernmost limit of the geographic distribution of $C$. armosa, and the populations of this region differ to the typical $C$. armosa by its dull-orange flowers, smaller anthers and shorter style branches.

\section{Acknowledgments}

We are indebted to Lidia Perez Molas and Tómas Rios by help during the trips from Paraguay, and Eduardo Alonso Paz (in memorian), Héctor Alejandro Keller and Andrés Gonzalez by value contributions during the trips performed in Uruguay and Argentina. The authors also are greatly thannkful of the collaborators of the herbaria mentioned in the text, for their contribution during the revision of material, and for providing images of exsiccates.

\section{References}

Azpiroz, A.B., J.P. Isacch, R.A. Dias, A.S. Di Giacomo, C.S. Fontana, \& C.M. Palarea. 2012. Ecology and conservation of grassland birds in southeastern South America: a review. Journal of Field Ornithology 83 (3): 217-246. http://dx.doi.org/10.1111/j.1557-9263.2012.00372.x

Baker, J.G. 1877. Systema Iridacearum. Journal of Linnean Society, Botany 16: 61-180. http://dx.doi. org/10.1111/j.1095-8339.1877.tb00172.x

Baker, J.G. 1892. Handbook of the Irideae. London: George Bells \& Sons, 248 pp. http://dx.doi.org/10.5962/bhl.title. 15431

Baker, J.G. 1903. Iridaceae Plantae Hassleriana. Bulletin de l'Herbier Boissier ser. 2, vol. 3: 1102-1106.

De Baltezán, M.M., A.M. dos Santos \& L.P. Deble. 2019. Cypella hauthalii (Kuntze) Foster subsp. opalina Ravenna (Iridaceae: Tigridieae) nueva cita para el Paraguay. Balduinia 65: 35-39.

Barker, C. 2020. World Checklist of Iridaceae. Facilitated by the Royal Botanic Gardens, Kew. Available from: http:// apps.kew.org/wcsp/ (accessed 4 January 2020).

Beauverd, G. 1923.VII. Nouvelles Iridacées de l'Uruguay. Bulletin de la Société Botanique de Genève, Sér. 2, 14: 163-167.

Beentje, H. 2010. The Kew Plant Glossary: an illustrated dictionary of plant terms. Royal Botanic Gardens, Kew, $160 \mathrm{pp}$.

Bilenca, D. \& F. Miñarro. 2004. Identificación de áreas valiosas de pastizal en las Pampas y Campos de Argentina, Uruguay y Sur de Brasil.Buenos Aires: Fundación vida silvestre, $353 \mathrm{pp}$.

Chauveau, O., L. Eggers, T.T. Souza-Chies \& S. Nadot. 2012. Oil-producing flowers within the Iridoideae (Iridaceae): evolutionary trends in the flowers of the New World genera. Annals of Botany London 110: 713-729. http://dx.doi. org/10.1093/aob/mcs 134

Chauveau, O., T. Pastori, T.T. Souza-Chies \& L. Eggers. 2014. Overlooked diversity in Brazilian Cypella (Iridaceae, Iridoideae): four new taxa from the Río de la Plata grasslands. Phytotaxa 174 (1): 25-42.

Deble, L.P., A.S. de Oliveira \& F.S. Alves. 2012a. Cypella discolor é redescoberta nos campos do Oeste e Sudoeste do Rio Grande do Sul: 68-79. In: Oliveira-Deble, A. S. de, Deble, L. P.\& A. L. S. Leão, Bioma Pampa: Ambiente $\times$ Sociedade, Ediurcamp, Bagé.

Deble, L.P., A.S. de Oliveira \& F.S. Alves. 2012b. Novo Registro de Cypella sect. Cypella (Iridaceae: Tigridieae). Balduinia 35: 19-26.

Deble, L.P., A.S. de Oliveira \& F.S. Alves. 2012c. Two new species of Cypella (Iridaceae: Tigridieae) from Rio Grande do Sul, Brazil. Phytotaxa 71: 59-68. http://dx.doi.org/10.11646/phytotaxa.71.1.12

Deble, L.P., F.S. Alves, A. González \& A.S. de Oliveira. 2015a. Three new species of Cypella (Iridaceae) from South America, and taxonomic delimitation of $C$. suffusa Ravenna. Phytotaxa 236 (2): 101-120. http://dx.doi.org/10.11646/phytotaxa.236.2.1

Deble, L.P., F.S. Alves \& A.S. de Oliveira. 2015b. Three new species of the genus Cypella (Iridaceae, Tigridieae). Darwiniana, nueva série 3 (2): 235-253. http://dx.doi.org 10.14522/darwiniana.2015.31.666

Deble, L.P. 2017. La identificación de Cypella exilis Ravenna (Iridaceae). Balduinia 56: 27-34.

Deble, L.P. \& F.S. Alves. 2017a. The type of Cypella herbertii subsp. brevicristata Ravenna (Iridaceae: Tigridieae). Balduinia 56: 20-26.

Deble, L.P. \& F.S. Alves. 2017b. Taxonomic novelties for the genus Cypella (Iridaceae): new species, synonymies and nomenclatural types. Kew Bulletin, Kew, vol. 72 (41): 1-18. 
Eggers, L., Marchioretto, R., Souza-Chies, T.T. \& O. Chauveau. 2019. A Taxonomic synopsis of Cypella (Iridaceae) in Brazil. Acta Botánica brasílica 33: 741-769.

Foster, R.C. 1950. Studies in the Iridaceae VI, Miscelaneous novelties and transfers. Contributions from the Gray Herbarium of Harvard University 171: 22-28.

Goldblatt, P. 1975. Revision of the bulbous Iridaceae of North America. Brittonia 27: 373-385.

Goldblatt, P. 1978. Herbertia (Iridaceae) reinstated as a valid generic name. Annals of the Missouri Botanic Garden 64: 378-379.

Goldblatt, P. \& J.C. Manning. 2008. The Iris Family. Natural History and Classification. Portland: Timber Press. 290 pp.

Hauman-Merck, L. 1909. Cypella nova Argentina. Apuntes de Historia Natural 1: 84-86.

Herbert, W. 1825. Tigridia herberti, Mr. George herbert's Tiger-flower. Botanical Magazine 52: t. 2599.

Herbert, W. 1826. Tigridia Herberti supra $\mathrm{N}^{\circ}$ 2599. Cypella. Botanical Magazine 53: t. 2637 (text 2).

Huaylla, H. \& J.R.I. Wood. 2012. Cypella boliviana (Iridaceae), a new species from Bolivia. Kew Bulletin 67: 1-4. http://dx.doi.org/10.1007/s12225-012-9401-5

Hurrel, J.A., G.G. Roitman \& G. Delucchi. 2009. Iridaceae: 251-326. In: Hurrel, J.A. Flora Rioplatense, Sistemática, ecologia y etnobotánica de las plantas vasculares rio-platenses. Parte 3 Monocotiledóneas, v. 4.

Jackson, B.D. 1893. Index Kewensis 1: 689.

Klatt, F.W. 1862. Specimen e familia Iridacearum. Linnaea 31: 533-570.

Klatt, F.W. 1871. Irideae: 510-548. In: Martius, C.F.P. von \& A. G. Eichler (eds.).Flora Brasiliensis 3 (1). Wolf, C. et fil. \& Minsinger, S., Munich.

Klatt, F.W. 1882. Ergantzungen und berichtgungen $\mathrm{zu}$ Baker's Systema Iridacearum. Abhandlungen der Naturforschenden Gesellschaft zu Halle 15: 44-404.

Kuntze, O. 1891. Phalocallis. Revisio generum plantarum 2: 702 .

Kuntze, O. 1898. Iridaceae. Revisio Generum Plantarum 3: 304-309. http://dx.doi.org/10.5962/bhl.title.327

León, B. 2006. Iridaceae endémicas del Perú. Revista peruana de Biologia 13 (2): 752-754.

Lindley, J. 1826. Moraea Herberti. The Botanical Register 11: pl. 949

Link, J.H.F. \& C.F. Otto. 1828. Ferraria pusilla. Icones plantarum selectarum 10: 125-126.

Munguía-Lino, G., O. Vargas-Ponce \& A. Rodriguez. 2017. Tigridieae (Iridaceae) in North America: floral diversity, flower preservation methods and keys for the identification of genera and species. Botanical Sciences 95 (3): 473-502.

Pastori T., L. Eggers, T.T. Souza-Chies \& O. Chauveau. 2018. Iterative taxonomy based on morphological and molecular evidence to estimate species boundaries: a case study in Cypella (Iridaceae: Iridoideae). Plant Systematics and Evolution 304: 1117-1140

Ravenna, P.F. 1964. Notas sobre Iridaceae. Revista del Instituto Municipal de Botánica, Buenos Aires 2: 51-60.

Ravenna, P.F. 1965. Notas sobre Iridaceae II. Boletin de La Sociedad Argentina de Botanica 10 (4): 311-322.

Ravenna, P.F. 1968. Iridaceae. In: Cabrera, A.L. Flora de la Provincia de Buenos Aires 4(1). Instituto Nacional de Tecnología Agropecuaria, Buenos Aires, Argentina, pp. 539-565.
Ravenna, P.F. 1977a. Notas sobre Iridaceae V. Noticário Mensal Museo Nacional História Natural 21: 7-9.

Ravenna, P.F. 1977b. Neotropical species threatened and endangered by human activity in the Iridaceae, Amaryllidaceae and allied bulbous families: 257-266. In: Prance, G.T. \&T.S. Elias (eds.) Extinction is forever. New York botanical Garden, New York.

Ravenna, P.F. 1981a. A submerged new species of Cypella (Iridaceae), and a new section for the genus (s.str.). Nordic Journal of Botany 1: 489-492. http://dx.doi.org/10.1111/j.1756-1051.1981.tb00714.x

Ravenna, P.F. 1981b. Eight new species and two new subspecies of Cypella (Iridaceae). Wrightia 7 (1): 13-21.

Ravenna, P.F. 1981. Kelissa a new genus of Iridaceae from South Brazil. Adansonia 1: 105-110.

Ravenna, P.F. 1983. Catila and Onira, two new genera of South America Iridaceae. Nordic Journal of Botany 3: 197-205. http://dx.doi.org/10.1111/j.1756-1051.1983. tb01065.x

Ravenna, P.F. 2000. Cypella laxa (Iridaceae) reported in the flora of Paraguay. Onira Botanical Leaflets 4: 1-2.

Ravenna, P.F. 2003a. The genus Phalocallis (Iridaceae). Botanica Australis 3: 1-7.

Ravenna, P.F. 2003b. Flora de Paraguay. Iridaceae. Botanica Australis 4: 1-60.

Ravenna, P.F. 2005. New species of South American bulbous Iridaceae. Onira Botanical Leaflets 10 (13): 39-45.

Ravenna, P.F. 2009. A survey in the genus Cypella and its allies (Iridaceae). Onira Botanical Leaflets 12 (1): 1-11.

Roitman, G.G. \& J.A. Castillo. 2004. Novedades en el género Cypella (Iridaceae). Boletín Sociedade Argentina Botánica 38: 337-339.

Roitman, G.G. \& J.A. Castillo. 2007. Novedades taxonómicas y nomenclaturales para la flora vascular del cono sur de Sudamérica: nuevas combinaciones en Iridaceae. Darwiniana 45: 236-241.

Roitman, G.G., I. Maza \& J.A. Castillo. 2008. Iridaceae. In: Zuloaga, F.O., O. Morrone \& M.J. Belgrano (eds.) Catálogo de Plantas Vasculares del Cono Sur 1. Monographs in Botany from the Missouri Botanical Garden 107: 423-453.

Soriano, A., R.J.C. León, O.E. Sala, R.S. Lavado, V.A. Deregibus, O. Cahuepé, A. Scaglia, C.A.Velazquez, \& J.H. Lemcoff. 1992. Río de la Plata grasslands. In: Coupland, R.T. (Ed.) Ecosystems of the World. Natural Grasslands. Introduction and Western Hemisphere. Elsevier, Amsterdam, p. 367-407.

Spegazzini, C. 1917. Ramillete de plantas argentinas nuevas o interesantes. Physis 3 (13): 37-46.

Tenore, M. 1845. Catalogo delle pianta che se coltivano nel R. Orto Botanico di Napoli Corredato della Pianta del Medesimo e di Annotazioni, Tipografia Della'Aquila di V. Puzziello, Napoli, 131pp.

Thiers, B. 2020. Index Herbariorum: A global directory of public herbaria and associated staff. New York Botanical Garden's Virtual Herbarium. Available from: http:// sweetgum.nybg.org/ih/ (accessed 15 March 2018).

Urban, I. 1893. Biographisce Skizzen. Systematic Pflanzen geschichte und Pflanzen geographie herausgegeben von A. Engler, Leipzig: 178-198.

Vellozo, J.M.C. 1831. Florae Fluminensis Icones 9. Senefelder, Paris, $130 \mathrm{pp}$. 
Deble, L.P. \& F.S. Alves, Cypella: What do we know?

\section{Index of names}

Accepted names are in bold.

Alophia brasiliensis 23

Alophia geniculata 24

Alophia unguiculata 24

Cypella 2, 3, 4, 5, 9, 19, 23, 24, 25

Cypella Alonsoana 8, 9, 20

Cypella amambaica 3, 9

Cypella altouruguaya 18

Cypella amplimaculata 13

Cypella aprica 13

Cypella aquatilis 5, 9

Cypella armosa 9, 11, 19

Cypella aurinegra 9

Cypella boliviana 3, 23

Cypella bonariensis 15

Cypella brasiliensis 23, 24

Cypella catharinensis $3, \mathbf{1 1}, 12$

Cypella charruana 11

Cypella craterantha 24

Cypella crenata 5, 11, 18

Cypella curuzupensis 3, 11, 12

Cypella discolor 12

Cypella elegans 24, 25

Cypella exilis 9, 13

Cypella fucata $11,13,18$

Cypella geniculata 24

Cypella gloriana 13, 21

Cypella gracilis 13

Cypella gracilis f. humilis 9

Cypella guttata 15, 21

Cypella Hauthalii 3, 5, 15, 19

Cypella Herbertii 3, 5, 17

Cypella Herbertii subsp. brevicristata 15, 17, 21

Cypella Herbertii subsp. Herbertii 11, 15, 17

Cypella Herbertii subsp. reflexa 17

Cypella Herbertii subsp. reflexa f. palmeti 25

Cypella Herbertii subsp. Wolffhuegelii 11, 17

Cypella laeta 17, 18

Cypella lapidosa 3, 9, 18

Cypella laxa 11, 18

Cypella luteogibbosa 11, 18, 20

Cypella magnicristata 18, 19, 23

Cypella opalina 5, 15, 19

Cypella opalina subsp. opalina 19

Cypella opalina subsp. minuticristata 19

Cypella oreophila 24

Cypella Osteniana 9, 19, 20

Cypella Osteniana subsp. aurantiaca 13

Cypella Pabstiana 3, 20

Cypella paludosa 11, 18

Cypella parviflora 15, 20, 21

Cypella pusilla 5, 13, 21

Cypella ramosa 15

Cypella Ravenniana 13, 21

Cypella rivularis 21

Cypella suffusa 17, 21, 23

Cypella trimontina 19, 23

Cypella uliginosa 23

Cypella unguiculata 24

Cypella yatayphila 17, 25

Dyckia spp. 23
Ferraria pusilla 21

Herbertia brasiliensis 23

Herbertia drummondiana 24

Herbertia Hauthalii 3, 15

Herbertia pusilla 21

Herbertia unguiculata 24

Hesperoxiphion 3, 4

Hesperoxiphion pusillum 21

Kelissa 3, 4, 24

Kelissa brasiliensis 23

Larentia 3, 4

Larentia linearis 25

Moraea Herbertii 15, 17

Onira 3, 4, 24

Onira unguiculata 24

Phalocallis 3, 4

Phalocallis coelestis 3

Phalocallis geniculata 23, 24

Phalocallis gracilis 13

Phalocallis Herbertii 15

Phalocallis Herbertii var. angustifolia 15

Phalocallis Herbertii var. latifolia 15

Phalocallis Herbertii var. normalis 15

Phalocallis oreophila 3,24

Phalocallis paludosa 11

Phalocallis pusila 21

Polia 5

Polia brasiliensis 15

Polia bonariensis 15

Polia gracilis 13

Polia ramosa 15

Sisyrinchium crenatum 11

Sphenostigma geniculatum 24

Sphenostigma gracile 13

Sympa riograndensis 24

Tigridia Herbertii 15, 17

Trifurcia brasiliensis 23

Trifurcia Hauthalii 15

Trifurcia unguiculata 24 